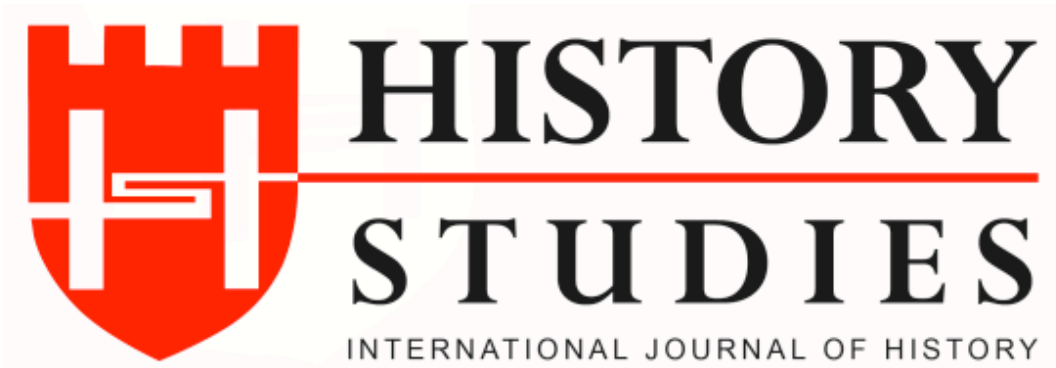

ISSN: 13094173 (Online) 1309 - 4688 (Print)

Volume 9 Issue 4, p. 63-99, November 2017

DOI: $10.9737 /$ hist.2017.551

\title{
Osmanlı Taşrasına Telgraf Hattı Çekilmesinde Yaşanan Zorluklar Niksar-Erbaa-Tokat Telgraf Hattı Örneği
}

The Troubles in the Installation of the Telegraph Line to the Ottoman Rural

A Case Study of Niksar-Erbaa-Tokat Telegraph Line

\author{
Yrd. Doç. Dr. Murat HANILÇE \\ (ORCID: 0000-0003-0587-9336) \\ Gaziosmanpaşa Üniversitesi - Tokat
}

\begin{abstract}
Öz: Bu çalışmada Erbaa-Niksar-Tokat arasında bir telgraf hattı çekilmesi konusu ele alınmıştır. Çalışmanın amacı bu telgraf hattı örneğinden yola çıkılarak Osmanlı Devleti'nin ana hatları dışında kalan ikinci ve üçüncü derece yerlerin telgrafa olan isteğini, hattın gelmesi sürecinde yaşanan sikıntılarl ve zorlu prosedürü ortaya koymaktır. 1880'de Tokat liva statüsüne erişince kendisine yeni bağlanan ve hiç telgrafi bulunmayan Amasya livasinin Erbaa kazası ve Ünye üzerinden Canik'e telgraf bă̆l olan Niksar kazalarının yeni liva merkezine bir hatla bağlanması zorunlu olmuş; 1880'den 1896'ya kadar süren uzun yazışmalar ve bürokratik girişimler sonunda Erbaa bir hatta kavuşmuştur. Çalışmanın başlıca kaynağı konuyla ilgili arşiv belgeleridir. Çalışmada yer yer Trabzon ve Sivas Vilayeti Salnamelerine de başvurulmuştur.
\end{abstract}

Anahtar Kelimeler: Erbaa, Niksar, Tokat, telgraf, ara hatlar.

\begin{abstract}
In this study, the issue of installation a telegraphic line between Erbaa-Niksar and Tokat is discussed. The aim of the study is to reveal the desire of the second and third degree places which are out of the main lines of the Ottoman State by moving from the example of this telegraph line and reveal the experienced difficulties and challenging procedure in the process of line arrival. In 1880, when Tokat reached the liva status, it has become obligatory for the new liva center to be connected with a line that Erbaa district of Amasya liva's, newly connected to Tokat and having no telegrams and Niksar district with telegraphic links to Canik via Ünye and from 1880 to 1896, Erbaa got to the line after a long correspondence and bureaucratic initiative. The main source of the work is archival documents related to the subject. In the study, it was occasionally applied to the annuals of the provinces of Trabzon and Sivas.
\end{abstract}

Keywords: Erbaa, Niksar, Tokat, Telegraph, Secondary Lines.

\section{I.Giriş:}

Yunanca tele (uzak) ve graphein (yazmak) sözcüklerinden türetilen telgraf sözcüğü 18. yüzyılın sonlarında ortaya çıkmıştır' ${ }^{1}$. ABC'sel mesajları bir uzaklığa ve uygun bir hızla ileten ilk telgraf sistemlerinden birisi 1794 'te Paris ve Lille kentleri arasinda kurulan her ara istasyonda dürbünle gözlenebilen devinimli kollar kullanan Chappe Telgrafi'dır. 1832'de ABD'li ressam Samuel Morse, ilk elektro-mıknatıslı telgrafını yaptı. Morse ve yardımcısı bu aleti daha sonra geliştirdi. Nokta ve çizgilerden oluşan bir kodlama sistemi geliştirdiler. Bu kodlama, daha sonra dünyanın genelinde kabul gören Mors Alfabesinin ilk adımıydı. ABD’de ilk telgraf hattı 1843 'te Washington ile Baltimore Maryland arasına çekildi ${ }^{2}$. Amerikan ve

\footnotetext{
${ }^{1}$ Ana Britanica, "Telgraf", C. 20, Ana Yayınc1lı, İstanbul 2000, s. 507.

2 Büyük Larousse, “Telgraf”, C. 22, Milliyet Yayını, İstanbul 1986, s. 11389.
} 
İngiliz ortak girişimi olan Trans-Atlantik telgraf hattının 15 Ağustos 1858'de başarıyla tamamlanmasını kutlamak amacıyla İngiliz Kraliçesi Victoria'nın gönderdiği telgraf Amerika'ya 16 saatte ulaşmıştı ve bu o zamanın koşullarında devrim niteliğinde bir gelişme say1lmaktayd1 ${ }^{3}$

Şu ana kadar Osmanlı Devleti'nde telgrafla ilgili müesseselerin kurulması ve telgraf hatlarının çekilmesine dair çok sayıda çalışma yapılmıştır ${ }^{4}$. Osmanlılar zamanında telgraf

\footnotetext{
${ }^{3}$ Robert O. Woods, "Makine Tarihi: Dünyayı Küçülten Bir Telgraf Hattı-A Cable to Shrink the Earth", çev. Yeliz Demir, Mühendis ve Makina, C. 52, S. 615, Nisan 2011, s. 41.

${ }^{4}$ Kitaplar: Yurda Güven Bezaz, Haberleşme ve Tarihçesi, Türkiye Haber İş Sendikası Yayını, Ankara 2006; PTT Genel Müdürlüğü, Geçmişten Günümüze Posta, PTT Genel Müdürlüğü Yayını, Ankara 2007; Asaf Tanrıkut, Türkiye'de Posta ve Telgraf ve Telefon Tarihi Teşkilatı ve Mevzuatı, Efem Matbaacılık, Ankara 1984; Tanju Demir, Türkiye'de Posta Telgraf ve Telefon Teşkilatının Tarihsel Gelişimi (1840-1920), PTT Yayınları, Ankara 2006; Şekip Keskin, Türk Posta Tarihi, Ulusal Matbaa, Ankara 1942; A. Baha Gökoğlu, Batı ve Doğu'da Telgrafçılık Nasıl Doğdu?, İstanbul 1935. Tezler: Nesimi Yazıcı, Osmanlı Devleti'nde Posta Teşkilatı (Tanzimat Devri), (Ankara Üniversitesi İlahiyat Fakültesi Yayımlanmamış Doktora Tezi), Ankara 1981; Mustafa Kaçar, Osmanl Telgraf İșletmesi (1854-1871), (İstanbul Üniversitesi Sosyal Bilimler Enstitüsü Yayımlanmamış Yüksek Lisans Tezi), İstanbul 1984; Ayşegül Okan, The Ottoman Postal and Telegraph Services in the Last Quarter of the Nineteenth Century, (Boğaziçi Üniversitesi Atatürk İlkeleri ve İnkılap Tarihi Enstitüsü Yayımlanmamış Yüksek Lisans Tezi), İstanbul 2003; Tanju Demir, Türkiye'de Posta ve Telgraf ve Telefon Örgütünün Tarihsel Gelişimi 1840-1920, (Dokuz Eylül Üniversitesi Atatürk İlkeleri ve İnkılap Tarihi Enstitüsü Doktora Tezi), İzmir 2001; Bahri Ata, The Transfer of Telegraphy Technology to the Ottoman Empire in the XIXth Century, (Boğaziçi Üniversitesi Sosyal Bilimler Enstitüsü Yayımlanmamış Yüksek Lisans Tezi), İstanbul 1996; Diren Çakılcı, Rumeli Telgraf Hatları (1854-1876), (Akdeniz Üniversitesi Sosyal Bilimler Enstitüsü Yayımlanmamış Yüksek Lisans Tezi), Antalya 2015; Esin Altun, Doğu Anadolu Bölgesi’ne İlk Telgraf Hatlarının Çekilmesi, (Atatürk Üniversitesi Sosyal Bilimler Enstitüsü Yayımlanmamış Yüksek Lisans Tezi), Erzurum 2011; Seyfi Toptaş, İttihat ve Terakki Cemiyeti ve Osmanlı Posta ve Telgraf Teşkilatı, (Gazi Üniversitesi Sosyal Bilimler Enstitüsü Yayımlanmamış Yüksek Lisans Tezi), Ankara 2004; Esin Tokmak, Prizren'deki 19. Yüzyıl Osmanlı Dönemi Kamu Yapılarının İncelenmesi ve Prizren Eski Posta ve Telgraf Binası İçin Koruma Önerisi, (Mimar Sinan Güzel Sanatlar Üniversitesi Fen Bilimleri Enstitüsü Yayımlanmamış Yüksek Lisans Tezi), İstanbul 2012. Makaleler: Roderic Davison, "The Advent of the Electric Telegraph in the Ottoman Empire", Essays in Ottoman and Turkish History, 1774-1923, University of Texas Press, Texas 1990, s. 133-165. Türkçesi için bk. Roderic H. Davison, "Osmanlı İmparatorluğu'na Elektrikli Telgrafın Girişis" Çev: Durdu Mehmet Burak, OTAM (Ankara Üniversitesi Osmanlı Tarihi Araştırma ve Uygulama Merkezi Dergisi), S. 14, Ankara 2003, s. 347-386; Özkan Keskin-Ali Sönmez, "Telgraf' ın Osmanlı İmparatorluğu'nda Yayılması: Çanakkale Telgraf Hattı Örneği”, OTAM, S. 25, Bahar 2009, s. 67-81; Uğur Akbulut, "Suriye’ye İlk Telgraf Hatlarının Çekilmesi", History Studies, C. 2, Ortadoğu Özel Sayısı, 2010, s. 1-11; Nesimi Yazıcı, "Telgrafçılık Tarihine Bir Bakış ve Osmanlı Telgrafçılığının Başlaması (Türkiye'de İlk Telgrafı Abdülmecit Çekti)”, Yıllarboyu Tarih, S. 7, Temmuz 1981, s. 23-26; Nesimi Yazıcı, "Osmanlı Telgraf Fabrikası”, Türk Dünyası Araştırmaları Dergisi, S. 22, Şubat 1983, s. 69-81; Nesimi Yazıcı, "Osmanlı Telgrafında Dil Konusu”, Ankara Üniversitesi Illahiyat Fakültesi Dergisi, S. 26, 1983, s. 751-764; Nesimi Yazıc1, "Tanzimatta Haberleşme ve Kara Taşımacılı̆̆ı", OTAM, S. 3, 1992, s. 333-375; Ahmet Yüksel, "Suçluluk ve Suçsuzluk Arasında Osmanlı Telgraf Memurları", Uluslararası Sosyal Araştırmalar Dergisi, C. 7, S. 33, 2014, s. 373-389; Erkan Tural, "Osmanlı Posta Bürokrasisi 1908-1914”, Ankara Üniversitesi Tarih Araştırmaları Dergisi, C. 28, S. 46, 2009, s. 205-230; Diren Çakılcı, “Osmanl1-Avrupa Telgraf Hatlarında Sırbistan Emareti'nin Rolü”, OTAM, S. 34, Güz 2013, s. 59-81; Diren Çakılcı, "Kıbrıs'ta Osmanlı Telgraf İșletmesi", İstanbul Üniversitesi Edebiyat Fakültesi Tarih Dergisi, S. 62, 2015/2, s. 65-90; Diren Çakılcı, "Osmanlı Devleti’nde Uluslararası Telgraf İşbirliği: Sicilyateyn/İtalya Örneği”, Yakın Dönem Türkiye Araştırmaları, C. 13, S. 25-26, 2014, s. 51-81; Yakub Ahbab, "İletişimde Yeni Dönem: Üsküp’te Telgraf", Yakın Dönem Türkiye Araştırmaları, C. 13, S. 25-26, 2014, s. 83-97; Said Olgun, "Posta ve Telgraf Mektebi Talimatnamesi”, Yakın Dönem Türkiye Araştırmaları, C. 13, S. 25-26, 2014, s. 149-181. Bildiriler: Neriman Ersoy Hacısalihoğlu, "Kırım Savaşında Haberleşme: Varna Telgraf Hattı Şebekesi”, Savaştan Barışa: 150. Yıldönümünde Kırım Savaşı ve Paris Antlaşması (1853-1856) Bildiriler, İstanbul Üniversitesi Tarih Araştırma Merkezi Yayını, İstanbul 2007, s. 119-130; Diren Çakılcı, "Kıbrıs'a Telgrafın gelişi: Lazkiye-Agios Theodoros Denizaltı Telgraf Hattı", Osmanlı Döneminde Kıbrıs Uluslararası Sempozyumu (9-11 Ekim 2015) Bildiriler, Bağcılar Belediyesi Yayını, İstanbul 2016, s. 526-536; İbrahim Serbestoğlu-Abidin Temizer, "Amasya'da Telgraf Hatlarının Çekilmesi”, Uluslararası Akdeniz Medeniyetleri Sempozyumu (8-10 Kasım 2016 Girne) Bildiri Kitabı, Gece Kitaplığ1, Ankara 2017, s. 83-90; Mehmet Mercan, "Giresun Telgraf İdaresi ve Telgrafhane Binası (18691904)", Uluslararası Giresun ve Doğu Karadeniz Sosyal Bilimler Sempozyumu (09-11 Ekim 2008) Bildiriler, C. 1, Ankara 2009, s. 354-366
} 
konusunda bu kadar çok çalışma bulunmasına rağmen bu çalışmaların büyük çoğunluğunun ortak noktası meseleye bütüncül yaklaşmalarıdır. Yerel çalışmalarda dikkat çeken nokta daha çok önemli güzergâhların ve ana telgraf hattı üzerinde bulunan merkezlerin çalışılmasıdır. Bununla birlikte, şu ana kadar ana telgraf hatları dışında kalan tali diyebileceğimiz ikinci ve üçüncü derece hatların kurulması ve bu hatların oluşturulması konusunda yerel idarelerin ve ahalinin çabalarını konu alan bir çalışma yapılmamıştır. Bu çalışma 1880'de Tokat'ın sancak olması üzerine buraya bağlanan Erbaa ve Niksar kazalarının mutasarrıflık merkezine bir telgraf hattıyla bağlanmasını konu edinmektedir. Çalışma 1887'den 1896'ya kadar yaklaşık dokuz sene boyunca Erbaa'nın bir telgraf hattına kavuşmak için ortaya koyduğu özveriyi, Osmanlı topraklarında küçük bir merkezin bile telgraf gibi bir yeniliğe olan açlığını ortaya koymayı amaçlamaktadır. Çalışmanın başlıca kaynağı Başbakanlık Osmanlı Arşivi'nden temin edilen belgelerdir. Çalışmada zaman zaman dönemin vilayet salnamelerine de başvurulmuştur. Çalışmada sırasıyla Osmanlı Devleti'ne, Sivas'a ve Tokat'a telgraf hatlarının gelişi üzerinde durulmuş; daha sonra Niksar-Erbaa-Tokat arasındaki hattın açılması için yapılan girişimler etraflıca değerlendirilmiştir.

Osmanlı Devleti'ne demiryolunun geldiği 1856 'da dünyanın ilk demiryolu hattı olan İngiltere'nin Stockton-Darlington hatt1 31; telgrafin geldiği 1855 senesinde İngiltere'nin Paddington-Drayton telgraf hattı henüz 18 yaşındaydı. $\mathrm{Bu}$ açıdan demiryoluyla karşılaştırıldığında telgraf Osmanlı topraklarına daha hızlı bir giriş yapmıştır. Bunun başlıca nedeni telgrafın sağladığı kolaylıklar ve maliyetinin az olmasıdır. Aslında, Osmanlı Devleti'nde ilk telgraf denemeleri telgraf hatlarının kurulmasının daha öncesinde gerçekleştirilmiş̧tir. Osmanlı Devleti ilk olarak semafor telgrafı denemiştir. 1828-1829 Rus Savaşı'nın ilk aylarında denenen semafor telgraf pek kullanışlı değildi ve yalnız İstanbul Boğazı'nın iki yakasından haberleşmeye olanak sağlıyordu. Elektrikli telgraf Samuel Morse'un çalışan bir telgraf makinesi icat etmesinden dört sene sonra 1839'da İstanbul'da denenmek istenmiştir. Morse'la birlikte çalışan bir Amerikalı olan Chamberlain İstanbul'a bu aracı getirmiştir. Ne var ki aracın çalıştırılması için bazı denemelerden daha geçmesi gerekmekteydi. Chamberlain bu denemeleri yapabilmek için Viyana'ya hareket etmiştir. Chamberlain'in bindiği vapurun Tuna'da alabora olup kendisi boğulup yaşamını yitirince beklenen telgraf denemesi hayata geçememiştir. 1847'de Amerikalı jeolog Lawrence Smith Beylerbeyi Sarayı'nda Sultan Abdülmecid huzurunda başarılı bir deneme yapmıştır ${ }^{5}$.

\section{Gelişimi}

II.Osmanlı Devleti’nde İlk Telgraf Hatlarının Kurulması ve Telgraf Örgütünün

Osmanlı Devleti'nde ilk telgraf hattı Smith'in denemesinden 6-7 yıl sonra Kırım Savaşı (18531856) sırasında Fransız ve İngilizler tarafından kurulmuştur. 1854'te hizmete giren, 340 mil

\footnotetext{
${ }^{5}$ Davison, agm, s. 348-349. 1839'da Morse'un ortağ ${ }_{1}$ Chamberlain yeni icad edilen telgraf makinelerinden birisini İstanbul'a getirmiştir. O sıralarda Morse, telgrafı Paris'te denemekteydi. Chamberlain'in amacı önce Osmanlı devlet adamları, daha sonra Avusturyalılardan bu yeni makine için patent almaktı. İstanbul'da yapılan denemelerde rakamları bazen eksik yazması üzerine Chamberlain aleti Viyana'ya götürüp yeniden gözden geçirip daha sonra İstanbul'da denemeyi düşünmüş̧ür. Tuna yoluyla Viyana yolculuğuna çıkan Chamberlain ve beraberindekilerin içerisinde bulunduğu gemi yolda batmış ve gemide bulunanlar yaşamını yitirmiş; böylece bu ilk girişim sonuçsuz kalmıştır. Bk. Cyrus Hamley, Among the Turks, New York 1876, s. 185. Türkiye'de bir maden okulu açmakla görevli olan Amerikalı Prof. Lawrence Smith 1847'de İstanbul ile yakın bir şehir arasında telgraf hattı kurmak amacıyla Amerika'dan bir telgraf makinesi takımı getirttirmiş, önceki denemeye nazaran oldukça gelişmiş bir makineyle gerçekleştirilen bu ikinci deneme Padişah Abdülmecid'in huzurunda Beylerbeyi Sarayı'nda gerçekleştirilmiştir. Hatta makine bizzat padişah tarafından kullanmıştır. 9 Ağustos 1847'deki bu deneme ertesi gün devlet erkanı huzurunda yinelenmiştir. Prof. Smith'e padişah tarafından bir nişan sunulmuş ve kendisine İstanbulEdirne arası bir telgraf hattı kurması için teklifte bulunulmuştur. Aleti çok beğenen Abdülmecid, aletin mucidi olan Morse'a Ocak 1848 tarihini taşıyan bir nişan da vermiştir. age, s. 194.
} 
uzunluğa sahip bulunan ve o tarihte dünyadaki en uzun sualtı telgraf kablosu olan bu hat Kırım Yarımadasındaki Balıklava ile Bulgaristan sahilindeki Varna'yı birbirine bağlamıştır. Telgrafın ilk denenmesine göre 6-7 yıl geç tesis edilmeye başlanması devletin imkânlarının yetersizliğine bağlanabilir ${ }^{6}$.Bu hattı Fransızların açtığı Varna-Rusçuk ve İngilizlerin açtığ Varna-İstanbul kabloları takip etmiştir. Bu ilk hatlar askeri amaçlarla kurulduğu için halk tarafından kullanılmamıştır ${ }^{7}$. Tanzimat Fermanı'nın yayımlanmasının ardından halkın da yararlanabileceği bir posta teşkilatı kurma çalışmalarına ağılık verilmiştir. ${ }^{8}$.

Telgraf, ilk başlarda Osmanlı Devleti'ne her ne kadar askeri ihtiyaçların sonucu girmiş olsa da zamanla resmi ve özel haberleşmenin aracı olmuştur. Osmanlı İmparatorluğu'nda telgrafın kullanıldığı alanlardan birisi İstanbul, Trabzon, Çanakkale, Selanik, Sakız, İzmir, Beyrut, Bağdat gibi şehirlerde bulunan rasathanelerden gelen gökyüzü gözlem raporlarının iletilmesiydi. Bu rasathanelerin gözlem raporları her gün İstanbul'daki merkeze iletilmekteydi. İstanbul'daki rasathane de bu gözlemlerin bir özetini hazırlayıp bir sonraki sabah Paris, Berlin, Viyana, Roma, Petersburg gibi Avrupa merkezlerinde bulunan rasathanelere iletirdi. Avrupa merkezleri de kendi raporlarını İstanbul'a telgrafla iletmekteydi. O dönemde ulaşım ve ticaretin çoğunlukla deniz yollarına bağlı olarak sağlandığı göz önüne alındığında merkezler arası gönderilen gözlemler ve hava raporlarının limanlara ulaştırılması oldukça önemliydi. Telgraf devletlerarası ilişkilere yeni bir boyut da kazandırmışıtır. Telgraf sayesinde önceki iletişim araçlarına kıyasla oldukça kısa sürelerde gönderilebilen mesajlar ve raporlar diplomasinin eski yöntemlerinin yerini almaya başlamıştır. Bu yeni teknolojiden yararlanan devletler kendi sınırları dışında olup bitenden daha erken haber almaya başlamışlardır. $\mathrm{Bu}$ durum diplomatları daha hızlı karar almaya sevk etmiştir. Bu etki ve yararlarına karşın Anadolu'da telgrafın yayılması umulduğu kadar hızlı olmamıştır. Stratejik olmayan yerlerde telgraf hatlarının inşası ya ihmal edilmiş ya da bu hatların kurulması için demiryolu bağlantısının kurulması beklenebilmiştir. Telgraf fiyatları uzun yıllar çok yüksek seviyelerde olduğundan halk bu teknolojiden ilk geldiğinde etkin şekilde yararlanamamıştır. Örneğin, 1880 'de Kayseri'de telgraf hattı bulunmasına rağmen teknik personel yetersizliğinden piller ve tellere yeterince bakım yapılamadığından telgraf merkezi çok zor işleyebilmiştir 9 .

Osmanlı Telgraf İdaresi 1855 y1lında kurulmuş; 1871'de Posta Nezareti'yle birleştirilmiştir. Türkiye'de telgraf hatlarının inşasında ve kullanımında yabancılara çok sınırlı ölçüde imtiyaz verilmiş; telgraf müessesi kuruluşundan itibaren devletin kontrolü ve idaresinde kalmıştır. Devlet merkezi otoritesini güçlü tutmak ve taşradaki hâkimiyetini pekiştirmek maksadıyla telgraftan azami ölçüde yararlanmak istemiştir. Telgraf için gerekli bazı malzeme ve teknik eleman ihtiyacını ilk başlarda İngiltere ve Fransa gibi yabancı devletlerden karşılama yoluna gitmiştir. Bazı hatlar, sermayesi Osmanlı Devleti tarafından karşılanmak üzere, başta

\footnotetext{
${ }^{6}$ age, s. 194. Ayrıca bk. Nesimi Yazıcı, "Telgrafçılık Tarihine Bir Bakış...”, s. 25.; Davison, agm, s. 349. Kırım Savaşı sırasına Fransızlar ve İngilizler cephe ile karargâhları arasında telgraf hatları kurarken öncelikle kendi silahlı kuvvetlerinin ihtiyacını düşünmüşlerdir. Bu meyanda İngilizler Varna'dan Kırım'daki Balıklava'ya bir hat çekmek istemiş ve bunun için $600 \mathrm{~km}$. uzunluğunda bir kablo denizaltından geçirilmiştir. 10 Nisan'da Bulgaristan'da denize indirilen kablo 18 Nisan'da Kırım'da karaya çıkarılmıştı Gökoğlu, age, s. 47. 17 Aralık 1854'te Varna-Rusçuk hattı için müracaat eden Fransızlar 27 Aralık'ta Osmanlı Devleti'nden gereken izni almışlardır. Hattın bütün masrafları Fransızlar tarafından karşılanacaktı. Savaş bittiğinde söz konusu hat Osmanlı Devleti'ne ait olacaktı ve bu hat gelecekte şekillenecek Osmanlı telgraf şebekesine önemli bir katkı sağlayacaktı. Mustafa Kaçar, "Osmanlı Telgraf İşletmesi”, Çağını Yakalayan Osmanlı, Ed. Ekmeleddin İhsanoğlu, IRCICA Yayını, İstanbul 1995, s. 48.

${ }^{7}$ Gökoğlu, age, s. 47.

${ }^{8}$ Eskin, age, s. 16.

${ }^{9}$ Demir, age, s. 55-56.
} 
İngiltere olmak üzere yabancı devletlere yaptırılmıştır ${ }^{10}$. Başlangıçta bir komisyon tarafından yürütülen Osmanlı telgraf idaresi kısa süre sonra Telgraf Müdürlüğ̈̈ şeklinde örgütlenmiştir. Posta Nezareti ile 21 Eylül 1871'de birleşinceye kadar idare, müdürlük seviyesinde çalışmalarını sürdürmüştür. Posta Nezareti ile birlikte Nafia Nezaretine bağlı olarak çalışmalarına devam eden Telgraf Müdürlüğü 1871 'de Posta Nezareti ile birleştirilmiş ve bu yeni idari yapı, Dahiliye Nezaretine bağlı olmak üzere, Posta ve Telgraf Nezareti olarak adlandırılmıştır ${ }^{11}$.

Telgrafhanelerin personel ihtiyacı ilk başlarda yapılan kontrat gereği yabancı memurların devletin belirlediği kişilere bu işi öğretmesi suretiyle karşılanmıştır. Ayrıca telgrafhanelerde usta-çırak ilişkisinde şakirdler bulundurulmuştur. Fünun-1 Telgrafiye Mektebinin 20 Ocak 1861 'de açılmasıyla Osmanlı Devleti kendi telgrafçılarını yetiştirmeye başlamıştır. Bu mektebi 1872'de açılan Posta ve Telgraf Mektebi takip etmiştir ${ }^{12}$. Osmanlı Devleti telgraf için gerekli makine ve teçhizatı uzun dönem dışarıdan ithal etmek zorunda kalmıştır. Bu bağımlılıktan kurtulmak maksadıyla $1869^{\prime}$ dan itibaren Osmanlı makine üretimine girişmiş ve zamanla bir Telgraf Fabrikası açmıştır ${ }^{13}$. İlk dönemde Osmanlı telgrafında haberleşme dili Fransızcaydı. Bunun başlıca nedeni ilk hatların malzemeleri kadar görevlilerinin de Fransa'dan getirilmesiydi. İlk Türkçe telgraf 3 Mayıs 1856 'da çekilebilmiştir ${ }^{14}$. Osmanlı Devleti, telgraf örgütlenmesini ve bu alandaki sorunları adım adım çözerken 19. yüzyılın son çeyreğine gelindiğinde halen telgrafı umutla bekleyen birçok merkez bulunuyordu ve bunlardan birisi de Erbaa'yd1.

\section{III.Sivas Vilayetinin Telgraf Hizmetine Kavuşması}

Sivas Vilayet merkezine telgrafin gelişinde İngilizlerin Londra-Hindistan arasında bir hat kurma çabalarının rolü büyüktür ${ }^{15}$. İngilizlerin bu projesinde Bağdat Hattı güzergâhı önemli bir yere sahipti. Bu güzergâh Üsküdar, İzmit, Ankara'dan geçip Sivas'a uğrayacak; oradan içerisinde yer alan Sivas-Yozgat arasındaki 53 saatlik mesafe 17 Cemaziye'l-evvel 1276/13 Aralık 1859 'da tamamlanmıştır. Böylece Sivas vilayet merkezi 1859 'da Osmanlı telgraf hattına dahil olmuştur ${ }^{16}$. 1870-1872 arasında Sivas'ta Telgraf ve Posta örgütü şu şekilde örgütlenmişti. Sivas merkezde bir Telgraf Müfettişliğ $i^{17}$ vardı. Bunun dışında Sivas, Amasya,

${ }^{10}$ Kaçar, agb, s. 46.

${ }^{11}$ Yazıcı, "Tanzimatta Haberleşme...", s. 346.

12 agm, s. 347.

${ }^{13}$ Yazıc1, "Osmanl1 Telgraf Fabrikası", s. 69-81.

${ }^{14}$ Yazıc1, "Osmanlı Telgrafinda Dil...”, s. 751-759.

15 Kaçar, agt, s. 51. İngilizler Hindistan-Londra telgraf bağlantısı için iki yol seçmişlerdir. Bunlardan birisi Akdeniz'den İskenderiye-Süveyş-Kızıldeniz güzergâhını takip edecek olan hattır. İkincisi Osmanlı toprakları üzerinden Basra Körfezinde ve buradan Hindistan hatlarına birleşen güzergâhtır.

${ }_{16}^{16}$ agt, s. 66.

${ }^{17}$ Telgraf Müfettişleri Osmanlı taşra telgraf idaresinde merkez ile taşra arasındaki iletişimde önemli bir yere sahipti. Müfettişlerin görevleri "Hutût-1 telgrafiye müfettişlerinin suret-i hareket ve vezâ‘if-i me'mûriyetlerine dâ'ir ta 'lîmât-1 mahsûsas1/Telgraf Hatları müfettişlerinin hareketleri ve görevlerine mahsus talimat" ile düzenlenmiștir. Talimatın birinci maddesinde müfettişin görevleri şu şekilde tanımlanmıştır: Müfettişlik memûriyeti belirli bir mesafede olan telgraf hatlarının korunmasıyla bu mesafe içerisinde bulunan telgrafhânelerde görevli bütün memurların görevlerini iyi şekilde yerine getirmesine dikkat ve gözetmeye münhasır olup müfettişler her sene ilkbahar ve sonbaharda iki defa memur oldukları mahallere gidecekler, yani kış mevsimi gelmeden önce direk ve tellerin bozulup fenalaşmış olanlarıyla kıştan sonra harap olanlarının gerekli tamîrâtını yerine getirme ve tellerin daima iyi halde olması için gereken tedbirlere teşebbüsle beraber başçavuş ve çavuşlara gerekli nasihatler ve tenbihler icrâsına girişecek ve bu iki sefer teftîşleri yalnız hatların tamîr ve ıslâhlarına özgü olmayıp yukarıda belirtildiği üzere memuriyet dairesinde görevli bütün memûrların hal ve hareketlerini ve mekatibat ve hâsılât-1 vâkıa defter muhâsebelerini ve makinelerin hal intizâmını görüp inceleyerek inhâsı gerekli olan maddeleri ayrıntılı olarak idare tarafina bildirecek ve memuriyet dairesi dâhilinde olan hattın ortasında veya ortasına civar olan bir merkezde 
Karahisar ve Tokat'ta telgraf ya da posta müdürleri ile bağlı personel bulunmaktaydı. Teşkilatta çalışanların ${ }^{18}$ sayısı 1872 senesinde 30'a ulaşmıştı (Bk. Ek-1). 1890'da personel sayısı 32 (Bk. Ek-2), 1903'te 74'e ulaşmıştı (Bk. Ek-3). 1872'de Sivas'tan telgraf gönderimi 20 kelime üzerinden değerlendiriliyordu. Vilayet içerisinde telgraf gönderimi 20 kelimesi 10 kuruştan hesaplanmıştı. Diğer vilayetlere gönderilecek telgraf ücretleri vilayetlerin Sivas'a uzaklığına göre değişmekteydi. Erzurum, Ankara, Trabzon, Halep, Kastamonu ve Konya gibi vilayete komşu ya da yakın vilayetlere telgraf gönderimi 20 kelimesi 15 kuruştan hesaplanmaktaydı. Aydın ve Edirne gibi uzak merkezlerde bu hesap 40 kuruşu bulmaktaydı. Bosna, İşkodra ve Yanya gibi Rumeli merkezlerinde bu rakam daha da yükseliyor ve 60 kuruşa erişiyordu (Bk. Ek-4) ${ }^{19}$. Sivas'ta posta dağıtımı tatar-sürücü ya da zabıta aracıllığıla

ikâmet edecek ve mu'âvinleri dahi bu işlerde istihdâm olunarak müfettişlerinin emri altında bulunacaklardır. Tamamı 13 madde olan 15 Safer 1290/14 Nisan 1873 tarihli bu talimat için bk. Düstur, Tertip I, C. 2, s. 368-373.

${ }^{18}$ Osmanlı Devleti'nde telgraf ağlarının düzenli çalışması için ilk nizamname 27 Rebiü’l-evvel 1276/24 Ekim 1859 tarihlidir. 12 fasıl 79 maddeden oluşmaktadır. Dört maddeden oluşan birinci fasıl devletlerin resmi mektuplaşması hakkındadır. Buna göre, Osmanlı Devleti'ne ait telgrafhanelerde telgraf çekmede öncelik Osmanlı resmi kurumlarına aittir. İkinci fasıl (5-7. Maddeler) tüccarların haberleşmesi hakkındadır. Burada da öncelik birinci fasılda olduğu gibi resmi kurumlara bırakılmıştır. Üçüncü fasıl (8-10. Madde) halkın haberleşmesine dairdi. Dördüncü fasıl (11-16. Maddeler) telgraf mektuplarının kontrolü hakkındaydı. Beşinci fasılda (17-21 maddeler) mektupların sırlarının ifşasının cezalandırılmasına ilişkin hükümleri içermekteydi. Altıncı fasıl (22. Madde) telgrafhaneleri çalışma saatlerini düzenlemekteydi. Buna göre Telgrâf odaları Nisan ayı başlangıcından Haziran ayı sonuna kadar sabah saat ondan gece saat dörde; Temmuz başlangıcından Eylül sonuna kadar sabah saat ondan gece saat beşe; Ekim başlangıcından Aralık sonuna kadar sabah saat birden akşam saat altıya ve Ocak başlangıcından Mart bitimine kadar sabah saat ikiden gece saat yediye kadar açık bulunacaktı. Cuma, Pazar, mübarek geceler, dini bayramlar veya Yortu günlerinde tatîl olunmayıp ve sıradan günlerin usûlüne halel gelmeyüb hergün işleyecekti ve her bir odanın açık ve kapalı bulunacağı vaktin saatleri kapısına yazılacaktı. Yedinci fasıl (23-36. Maddeler) gelen bir telgrafın sahibine ulaştırılmasına ilişkindi. Sekizinci fasılda (37-48. Madde) telgrafhanede çalışan muhabere memurlarının görevleri açıklanmıștı. Gerek İstanbul ve gerek memleket genelinde bulunan bütün telgrâfhâneler memûrları telgrâf genel idaresinin emri altında ve ma'iyetinde ve taşra telgrâfhâneleri memûrları merkez müdürlerinin ve merkez müdürleri de telgrâf müfettişleriyle muavinlerinin emri altında olacaktır (37. Madde). Taşra telgrâfhâne müdürleri telgrâf alıp vermek fennini tahsîl ve bulundukları mahallerde icraya mecbûr olacaklardır (38. Madde). Makinelerin telgrâf işinden başka bir şey için kullanılması yasaklanmış olduğundan bunların iyi şekilde korunmasına telgrâfhâne müdürleri özen gösterecektir (39. Madde). Muhâbere me'mûrları tarafından tahsis olunacak nöbete göre pil yani elektiriğin eczâlarını saklama ve koruma, kadeh ve fincânları bu hizmete tayîn olunan adama vaktiyle temizlettirmeye dikkat edecektir (40. Madde). Muhâbere memûrları kullandıkları makinelerinin gayet temiz olmalarına dikkat ile her gün nöbete girdikleri vakitte postayı muayene edip gerektiği takdirde her bir kundağı yani makinenin vidalarını temizleyeceklerdir (41. Madde). Taşra telgrâfhâne müdürleri ve refâkatlarında bulunan muhâbere memûrları karşılıklı muhabere icrası için nöbetleri vaktinde daima postada hazır olup yalnız yemek vaktinde postadan ayrılabilecekler ise de daima bir nefer nöbetle postayı bekleyecek ve gece nöbetlerini dahi icrâ eyleyeceklerdir (44. Madde). Telgrâf me'mûrlarının tamamı sınıf sınıf kendilerine özel elbiselerini dâimâ temiz hâlde olarak giyinmeye mecbûr olacaklardır (48. Madde). Dokuzuncu Fasıl (49-61. Maddeler) Telgrâfhâne Haberleşmesini Öğretmek İçin Telgrâfhâneye Alınacak Şakirdler Hakkında Olan Nizâm-nâmeden ibarettir. Onuncu Fasıl (62-71. Maddeler) Telgraf hattı muhâfazasına memûr süvâri ve piyâde çavuşların üzerlerine yüklenen vazife ve memûriyetlerine dairdir. Çavuşların başlıca görevi hatların kontrol edilmesi ve hatta gerekli olan bakımın sağlanmasıdır. Nizamnameye göre, teller ve diğer şeylerin hızla tamîri husûsu bütün çavuşların görevi olduğundan her gün gün doğumunda hattı dolaşmaya çıkacaklar ve telleri kış mevsiminde lüzumu kadar gevşetecekler ve yaz mevsiminde gereceklerdir ve sözkonusu tellerin ve porselenlerin üzerinden örümcekleri ve diğer fenalıkları temizleyeceklerdir (65. Madde). On birinci fasıl çavuşların kabahatleri ortaya çıktığında icra olunacak cezalandırmayı içermektedir (72-75. Madde). On ikinci ve son fasıl (76-79. Maddeler) ise Telgrâfhânelerde mektup ulaştırma hizmetinde görevli görevlilerin memuriyet görevlerine dairdir. Bir muvassıl-ı muharrerât sâhibine teslim olunmak üzere kendisine verilen telgrâf yazışmasının sâhibini gereği gibi aradıktan sonra o adam bir mahalle gitmiş veya vefât etmişse derhâl telgrâfhâneye gelip memuruna bildirecektir (77. Madde).Telgrâfhânelere bir saatten fazla uzaklığı olan yerlere mektup sahibini bulmak için muvassıl-ı muharrerâtın doğal olarak kayık ve beygir ücreti gibi masrafları ortaya çıkacağından bu masraflar da mektup sâhibi tarafından kendisine ödenecektir (78. Madde). Nizamname hakkında bk. Düstur, Tertip I, C. 2, s. 348-362.

1920 Kelimelik bir telgraftan İstanbul'a kadar alınacak ücret 1279/1862-1863 ve 1283/1866-67 senesinde Sivas'tan 82 kuruştu. 1289/1872 senesinde 35 kuruştu. Bk. Kaçar, agt, Ek-2, 3 ve 4. 
gerçekleştiriliyordu. 1872'de Amasya, Tokat, Yıldızeli, Divriği, Karayün ve Kayalı'ya tatarlar giderken; Kangal, Aziziye, Gürün, Darende, Zara, Tozanlı, Karahisar-1 Şarki ve Tonus gibi yerlere zabıtalar posta taşımaktaydı. Postada bazı aktarmalar da olmaktaydı. Örneğin Zara, Tozanlı ve Karahisar-1 Şarki postası her Pazartesi zabtiye ile Zara'ya ulaşıp oradan Tozanlı ve Karahisar'a aktarma yapılmaktaydı. Bunun gibi bir dağıtım merkezi de Deliktaş’tı (Bk. Ek-5).

\section{Tokat ve Zile'ye Telgrafın Gelişi}

Vilayet Nizamnamesi (1864)'nin 1867'de yeniden yayımlanmasiyla kurulan vilayetlerden birisi de Sivas'tır. Vilayet, ilk kurulduğunda üç sancak, 14 kaza ve 13 nahiyeden oluşan bir idari yapılanmayla şekillendirilmiştir. Vilayete bağlı sancaklar Merkez, Amasya ve Karahisar-1 Şarki'ydi ${ }^{20}$. Vilayet Nizamnamesi (1871) vilayetin bu idari yapısında bazı değişiklikler içermiştir. $\mathrm{Bu}$ değişiklilerden birisi Amasya Sancağında Ladik ve Maden-i Sim (Gümüşhacıköy)'in, Karahisar-1 Şarki Sancağında Alucra'nın kaza statüsü elde etmeleridir ${ }^{21}$. İkincisi 12 Ocak 1880 tarihinde, Sivas sancağına bağlı Tokat kazasının Sivas vilayetine bağlı mutasarrıflık (sancak/liva) şeklinde yeniden örgütlenmesidir ${ }^{22}$. Bu değişiklikler, doğal olarak vilayetteki kaza ve nahiye sayısını artırmıştır. 1884 yıllında Sivas Vilayeti, Merkez, Amasya, Tokat ve Karahisar-1 Şarki'yi içeren dört sancak ve bu sancaklar içerisinde yer alan 22 kaza, 233 nahiye ve 3071 köy sayısına erişmiştir ${ }^{23}$. 1890'lı yılların başında adı geçen sancaklar 26 kaza, 257 nahiye ve 4761 köyü kapsamıştır ${ }^{24}$. 20. yüzyılın başlarında bağlı sancaklar içerisinde yeni kazalar kurulmasıyla Sivas vilayetinin idari bölümlenmesi bir kez daha değişmiştir. 1903'te Sivas Sancağında Yenihan ve Kangal, 1908'de Tokat sancağında İskefsir kazaları teşkil edilmiştir. Bu değişikliklerle 1908 yılı itibarıyla vilayet, dört sancağıyla 23 kaza, 70

HISTORY STUDIES nahiye ve 3160 köy sayısına erişmiştir (Bak. Tablo 1) ${ }^{25}$ : Sivas vilayetinin bu idari bölümlenmesi, küçük değişikliklerle 1920 yılına kadar sürmüştür. Türkiye Büyük Millet Meclisi İcra Vekilleri Heyeti’nin 31 Mayıs 1920'de çıkardığı bir kararla Amasya ve Tokat vilayet yapılmıştır ${ }^{26}$.

Tablo 1. Sivas Vilayetinin 1908 Yılı İdari Taksimatı

\begin{tabular}{llll} 
Sancak & Kaza & Nahiye & Köy \\
Merkez (Sivas) & 10 & 34 & $\mathbf{1 2 7 8}$ \\
Amasya & 6 & 12 & $\mathbf{7 3 3}$ \\
Karahisar-1 Şarki & 4 & 6 & $\mathbf{4 6 1}$ \\
Tokat & 3 & 18 & $\mathbf{6 8 8}$ \\
\hline Toplam & $\mathbf{2 3}$ & $\mathbf{7 0}$ & $\mathbf{3 1 6 0}$
\end{tabular}

\footnotetext{
${ }^{20}$ Mehmet Mercan, "Sivas Vilayeti’nin Teşkili ve İdari Yapısı (1867-1920)", Osmanlılar Döneminde Sivas Sempozyuтu Bildirileri (21-25 Mayls 2007), C. 1, Sivas 2007, s. 551.

${ }^{21}$ agb., s. 555.

${ }^{22}$ Mehmet Mercan, "Tokat'ın Mutasarrıflık Oluşuna Dair Bir Belge”, Tokat Kültür Araştırma Dergisi, S. 17, Aralık 2002, s. 6-7; Ali Açıkel, "Tokat Sancağının İdari Durumu ve Nüfus Yapısı (1880-1907)” Fırat Üniversitesi Sosyal Bilimler Dergisi, C. 14, S. 2, Temmuz 2004, s. 333. Tokat'ın sancak statüsüne çıkarılmasına ilişkin Sivas Vilayeti'nden 14 Aralık 1879'da Dahiliye Nezareti'ne gönderilen yazıda Tokat ve çevresine ilişkin birçok konunun altı çizilirken yeni kurulacak sancağın sınırlarına da işaret edilmiştir. Buna göre Canik Sancağı'na bağlı olan Niksar Kazası'nın Samsun'a 25 saat mesafesi olduğu halde Tokat'a 8 saat mesafede bulunduğuna dikkat çekilerek, yakınlığından dolayı Tokat'a bağlanmasının güvenlik açısından uygun olacağı, bundan başka Amasya Sancağı'na bağlı olan Erbaa ve Zile kazalarının da Tokat'ın yakın çevresinde olması nedeniyle Tokat'a bağlanması dile getirilmektedir. Bk. Esat Aktaş, XIX. Yüzyılın Son Çeyreğinde Tokat, (Gaziosmanpaşa Üniversitesi Sosyal Bilimler Enstitüsü Yayımlanmamış Yüksek Lisans Tezi), Tokat 2009, s. 27-29.

${ }^{23}$ Şemseddin Sami, Kâmusü'l-Âlam, C. 4, İstanbul 1311/1884, s. 2798; Mercan, agb, 2007, s. 556.

${ }^{24}$ Vital Cuinet, La Turquie D'Asie Géographque, Administrative, Statistique, Descriptive et Raisonnée de L'Asiemineure, C. 1, Paris 1892, s. 614.

${ }^{25}$ Mercan, $a g b$, s. 557.

${ }^{26} a g b$, s. 558 .
} 
Tokat'ın Osmanlı telgraf ağına bağlanması yolunda ilk girişimler 1863 senesinde başlamışıır' ${ }^{27}$. Sivas Valisi tarafından sadaret makamına hitaben 18 numara ile res'en yazılan yazı bu konuyla ilgili eldeki ilk belgedir. Belgeden anlaşıldığına göre, bir vakitten beri Tokat'a telgrafhane açılması arzusuyla Tokatlı tüccarlar ve ahali tarafından yardım girişimlerine başlanmıştır. Valinin açıklamalarında telgraf Tokat'ın politikaya olan ilgisini korumak ve aynı zamanda verimli Tokat kalhanesinin işlerini kolaylaştırmak gibi faydalar sağlayacaktı. (11 Cemaziye'l-ahir sene [1]280/23 Kasım 1863) ${ }^{28}$.

Yukarıda belirtilen yazının eklendiği 424 numaralı ve 2 Receb [1]280/13 Aralık 1863 tarihli bir diğer belgeyle, konu telgraf idaresine iletilmiş ve idarenin görüşü sorulmuştur. Telgraf idaresinin 6 Receb [1]280/17 Aralık 1863 tarihinde konuyla ilgili belirttiği görüş şu şekildedir: Tokat hattının Yozgat ve Sivas'tan geçen Bağdat koluna eklendiği takdirde Hindistan muhaberatı için mevcut olan iki tel üzerine iki tel daha eklenmesinin gerekeceği vurgulanmıştır. Eski direklerin bu kadar teli taşıyamayacağından ötürü bu hat için yeniden direk temini ve dikilmesinin zorunlu olduğu belirtilmiştir. Hattın Amasya-Yozgat güzergahı yerine Tokat'tan geçirilmesi durumunda 4-5 saat mesafe farkı ortaya çıkacağ 1 , bu açıdan gerekli direk masrafı ve amele yevmiyesini ahalinin karşılaması önerilmektedir. Bu durumun soruşturulması gerektiği vurgulanmaktadır. Eğer halk kabul etmezse bu miktarın mal sandığından karşılanacağına işaret edilmiştir ${ }^{29}$.

Sivas Valiliğine 16 Receb 1280/27 Aralık 1863 tarihinde gönderilen cevabi tezkerede konunun telgraf idaresiyle görüşüldüğü belirtilmektedir. Konu Meclis-i Vala-y1 Ahkam-1 Adliye'ye havale edilmiştir. Bu yazıdan anlaşıldığı kadarıyla Meclis-i Vala konuya olumlu yaklaşmaktadır. Ne var ki meclis telgraf hattının direk temini, dikilmesi ve inşası gibi çeşitli masraflarının Tokat halkı tarafından karşılanıp karşılanamayacağının açık olmadığı ve bunun araştırılmasını istemiştir ${ }^{30}$.

Sivas Vilayetine 20 Rebiü’l-ahir sene 1285/10 Ağustos 1868 tarihinde gönderilen yazıdan Tokat'a gidecek telgraf hattının direk ve amele masrafının ahaliye yüklendiği anlaşılmaktadır. Öte taraftan telgrafhane ve hat için gerekli alet, edevat masrafi olan 12186 Frank ile memur maaşına karşılık gelen aylık 4522 kuruş hazineden karşılanacaktı. Tellerin nakli ile direk dikilmesi için gerekli meblağ mal sandıklarından temin edilecekti. Nafia Nezareti Tokat-Sivas hattı konusunda yaptığı yazışmalarla keyfiyeti Maliye Nezaretine bildirmişti. Hazır olan söz konusu edevatın ulaştırılması ile memurların seçimi ve gönderilmesi konusunda Sivas Valiliğine gönderilen tezkereden anlaşıldığına göre Maliye Nezareti gerekli harcama için yetkili kılınmıştır. Yine aynı belgeden anlaşıldığına göre ahaliden yalnız servet sahibi olanlar ile tüccarların telgrafhane masrafina katılması, diğerlerine bu konuda borç çıkarılmaması uyarısı yapılmıştır. Aynı yazı Maliye Nezaretine de yollanmış ve konunun vilayete bildirildiği bilgisi verilmiştir ${ }^{31}$. Böylece 1868 senesi itibarıyla Tokat-Sivas arası bir telgraf hattı kurulduğu

\footnotetext{
${ }^{27} \mathrm{Bu}$ tarih Samsun-Yozgat arası bir hat kurulmasının planlandığı bir tarihti ve Tokatlılar Samsun telinin Bağdat telgraf hattına bağlanması için gereken hattın Tokat'tan geçirilmesini talep ediyor ve böylelikle şehre telgrafın gelişini hızlandırmak istiyorlardı. 1863 senesi müfettiş Ali Rıza Efendi'nin Samsun'a gelip Samsunluların da şehirlerine telgraf çekilmesini arzu ettikleri seneydi. 1864 'te Samsun-Amasya teli çekildi. Ayrıntılı bilgi için bk. İbrahim Serbestoğlu- Temizer, $a g b$, s. 85. Osmanlı telgraf hatlarının bütün ülkeye yayılma çabalarında Anadolu'da üç önemli güzergâh vardı. Bunlar kuzey, güney ve batı kollarıydı. Kuzey kol içerisinde Üsküdar-Bağdat hattının kuzeyinde kalan kuzey kolu Batı Karadeniz Bölgesinden başlayarak bütün Karadeniz ve Doğu Anadolu’yu içerisine almaktaydı. Kol içerisinde Yozgat-Samsun Hattı önemli bir yere sahipti. Direkleri ahali tarafindan temin edilmek üzere 8 Muharrem 1280/24 Haziran 1863 tarihinde inşasına başlanmıştı. Bk. Kaçar, agt, s. 92.

${ }^{28}$ BOA (Başbakanlık Osmanlı Arşivi), Meclis-i Vâlâ (BOA. MVL.), 663/58, 23 Kasım 1863 (1280.C.11).

${ }^{29}$ BOA. MVL, 663/58, 13 Aralık 1863 (1280.B.6).

${ }^{30}$ BOA. MVL, 663/58, 27 Aralı 1863 (1280.B.16).

${ }^{31}$ BOA, A.MKT.MHM. (Sadaret Mektubi Kalemi Mühimme Evrakı),416/25, 10 Ağustos 1868 (1285.R.20).
} 
görülmektedir. Ancak bu hat Samsun-Amasya hattıyla birleştirilmemiş; doğrudan Tokat-Sivas arasında çekilmiştir.

Tokat çevresine telgraf hattı çekilen ilk kazalardan birisi o tarihlerde Amasya Sancağ 1 sınırları içerisinde yer alan ve daha sonra Tokat'a bağlanacak Zile'dir. ${ }^{32}$. Zile kazası ahalisi 1869 'da kazalarına Amasya üzerinden bir hat çekilmesi için bir dikekçe yazmışlardır ${ }^{33}$. Yine Zile kazasına telgraf hattından bir şube gerekli olduğuna dair Amasya Mutasarrıflı̆̆ına yazılan 15 Ramazan 1287/9 Aralık 1870 tarihli yazıda hattın direk vs. masraflarının meccanen karşılanacağı bilgisini ve Avrupa'dan gelecek tel ve edevat ile istihdam olunacak memur maaşının miktarını içeren bir pusula bulunmaktaydı ${ }^{34}$. Bu yazıya göre, hat için Avrupa'dan getirtilecek tel ve diğer aletler 8335 Frank, memur maaşları aylık 2166 kuruş tutarında olacakt1.

Sivas Vilayeti sınırları içerisinde telgraf hatlarının çoğalması için uğraşanların başında İsmail Hakk1 Paşa (valiliği 1880-82) ile Halil Rifat Paşa (valiliği (1882-85) gibi valilerin rolü oldukça önemlidir. Bilhassa İsmail Hakkı Paşa, valiliği esnasında vilayet içerisinde haberleşmeyi daha etkin ve kolay bir duruma getirmek gayesiyle telgraf hizmetlerinin yaygınlık kazanmasına dönük çalışmalara öncülük etmiştir. Onun valiliği sırasında 1880 yılında hizmete sokulan hatlardan birisi Tokat-Zile arasındaki teldir Ayrica aynı tarihlerde Erbaa, Suşehri, Divriği, Ladik, Gürün, Köprü, Maden-i Sim ve Osmancık hatlarının kurulması için girişimlere hız verilmiş̧; bununla birlikte hükümetten araç-gereç temini konusunda beklenen yardım sağlanamamış ve bu nedenle bu hatların kurulması ileri tarihlere ertelenmek zorunda kalmıştır. Söz konusu dönemde Kaymakam Halil Rahmi Bey'in gayreti ve halkın maddi yardımlarıyla yalnız Darende'de dört odalı bir telgrafhane hizmete başlayabilmiştir ${ }^{35}$.

\section{Niksar'a Telgrafın Gelişi}

Niksar, günümüzde idari yönden Tokat'a bağlı bir ilçedir. Karadeniz Bölgesi sınırları içerisinde Orta Karadeniz bölümünün iç kesiminde yer almaktadır. Tokat şehrine $54 \mathrm{~km}$. uzaktadır. İlçe, kuzey-batısında Erbaa, güney-batısında Tokat Merkez, güneyinde Almus, doğusunda Başçiftlik, güney-doğu ve kuzey-doğudan Reşadiye ve kuzeyinde Akkuş (Ordu) ilçeleri ile komşudur. Niksar, 1865-1880 yılları arasında Trabzon Vilayeti içerisinde yer alan Canik Sancağına bağlı kazalardan birisiydi ${ }^{36}$. 1880 'de Sivas Vilayetine bağlı Tokat Sancağının

${ }^{32}$ Zile doğusu Turhal, batısı Çekerek (Yozgat), kuzeyi Amasya ili, güneyi Artova (Tokat) ve Kadışehri (Yozgat) ilçeleri ile çevrili Tokat'a bağlı bir ilçedir. 17. yüzyılda Sivas'a bağlı bir sancak halinde bulunan Zile daha sonra kaza konumuna gerilemiştir. 1860 yılında Sivas'a bağlı Zile kazasının Amasya'ya bağlanması için halkın rızası olup olmadığı sorulmuş; 1862'de Sivas'a bağlı kalmasında yarar görülmüştür Bekir Altındal, Zela'dan Zile'ye Tarihi Yolculuk, İstanbul 2011, s. 97. 16 Mart 1865'te Turhal, ve Taşabad kazalarıla Amasya sancağına ilhak ettirilmiştir. Bk. BOA, MVL. 708/74, 16 Mart 1865 (1281.L.18). 1880'de ise sancaklık statüsü kazanan Tokat'a bağlanan Zile kazası günümüze kadar bu özelliğini korumuştur. Bk. Açıkel, agm, s. 333-334. 1882'de Zile kazası İsa-1 Sagir, Bazlanbac, Acısu, Hacıköy, Kösterelik, Söğütözü, Üçköy, Dikmesögüd, Kadışehri nahiyelerinden oluşmaktaydı. 1881 'de Zile Kazasında 44052 Müslim, 1796 Ermeni ve 138 Kıpti olmak üzere 45986 nüfus vardı. Nüfusun \% 95, 79'u Müslim'di. Bk. Aktaş, agt, s. 82 ve 93.

${ }^{33}$ Altındal, age, s. 279.

${ }^{34}$ BOA.İ.DH. (İrade Dahiliye) 43425/624, 9 Aralık 1870 (1287.15.N)

35 Kemalettin Kuzucu, "Osmanlı Modernleşme Sürecinde İki Sivas Valisinin Raporlarının Karşılaștırılması ve Vilayetin Kentsel Dönüşümüne Etkileri”, Osmanlılar Döneminde Sivas Sempozyumu Bildirileri (21-25 Mayıs 2007), C. 1, Sivas Valiliği İl Kültür ve Turizm Müdürlüğü Yayını, Sivas 2007, s. 344.

${ }^{36} 1864$ senesi Haziran ayına kadar Canik Sancağına bağlı bir kaza olan Ünye'nin bu tarihten sonra sancak haline getirilmesiyle birlikte Erbaa, Karakuş, Bolaman ve Fatsa kazalarıla birlikte bu sancağı teşkil eden kazalardan birisi de Niksar olmuştur. Söz konusu sancak eyalet merkezi Trabzon yerine Canik Sancağına bağlıydı. Bu sancağın oluşturulmasında hizmetlerin daha hızlı götürülmesi yanında güvenlik sorunlarının daha etkin çözülmesinin payı da önemliydi. Zira bu yeni idari yapılanma sonrasında Ünye-Niksar ve Erbaa arasında toplanan asker kaçakları ve eşkıya ile daha etkin bir mücadele planlanmaktaydı. Hatta bu amaçla Ünye-Niksar arasında bir karayolu açılması 
kurulmasıyla Zile ve Erbaa kazalarıyla birlikte bu sancağa bağlanmıştır ${ }^{37} .1894$ 'te Eskidir, Kuyucak, Avara, Kapıă̆zı, Olukalanı, Ladik, Meğdün, Başçiftlik ve Arguslu nahiyelerinde toplam 83köye sahipti ${ }^{38}$.

Canik Mutasarrıflığ Ünye hattına bağlanmasına ilişkin yazışmalar 1873'ten itibaren Niksar'a telgraf getirme çabalarının başladığını göstermektedir ${ }^{39}$. Canik Mutasarrıflığından 9 Zilkade [12]89/8 Ocak 1873 tarihinde Sadarete yollanan yazı Niksar telgraf evinin bağlanması ve buna ilişkin masraflarla ilgilidir. Mutasarrıflıktan yollanan yazıdan anlaşıldığına göre, Canik Sancağının diğer kazalarında olduğu gibi halkının yoğun isteği ve girişimleriyle Ünye kazasından geçen telgraf hattına bağlanmak üzere Niksar kazasında bir telgrafhanenin kurulması daha önceden kararlaştırılmıştı. Yazı daha önce yapılan yazışma üzerine kaza sakinleri tarafından yeni bir telgrafhane inşa edildiğini, daha sonra alınan cevap mazbatasında söz konusu hat için gereken direklerin iftihar edilecek bir hizmet olarak ahali tarafından kesildiği, söz konusu hat güzergâhına nakledildiği ve hazır hale getirildiğini bildirmekteydi. Kazada bir telgrafhane inşası devletin iyi işlerinden sayılmakta; Sadaret makamından telgrafhanede istihdam edilmek üzere gerekli memur, tel ve edevatın tayini ve gönderilmesi talep edilmekteydi ${ }^{40}$. 3 Rebiü'lEvvel sene [1]290/1 Mayıs 1873 tarihinde sadarete gönderilen ikinci yazı Niksar kazasında ahali tarafından yeni inşa ettirilen telgrafhane için gerekli memur, tel ve diğer edevatın yollanmasına izin verilmesiyle ilgilidir. Bu durum 127 numaralı ve 10 Zilkade sene [12]89/9 Ocak 1873 tarihli yazıya istinaden kaleme alınmıştı. Yazıda telgrafhane hattının sınırlarına naklettirilen ve hazırlanan sütunların kaybolacağı ya da zarar göreceğinin mahalline mazbatayla duyurulduğu belirtilmekteydi. Bu nedenle memur, tel ve edevatın gönderilmesi talebi yinelenmekteydi ${ }^{41}$.

19-20 Rebiü'l-evvel [1]290/17-18 Mayıs 1873 tarihli yazı ${ }^{42}$ istenen alet edevat ve memurların ulaştırılması hakkında mahallinden gelen yazıya cevap olarak Telgraf Nezaretinin hazırlayıp Sadarete sunduğu tezkereyle ilgilidir. Tezkere eşya masrafının 13724 Frank ve memurların maaşının aylık 1800 kuruş olacağını göstermekteydi. Bu yazıdan anlaşıldığ 1 kadarıyla Niksar telgraf hattının masrafları o sene bütçesinden karşılanacak durumdaydı. Yazının altındaki ifadelerden bu harcamanın yapılabileceği ve bu konuda inisiyatifin Telgraf Nezaretine bırakıldığı anlaşılmaktadır.

gündeme gelmiştir. 1 Ağustos 1864 'te yapımına başlanan Ünye-Niksar karayolunda ilk araba 23 Eylül 1864 'te Niksar'dan Ünye'ye ulaşmıştır. Bu yol günümüzde Orta Karadeniz bölümünün iç kesimlerinde yaşayan insanların sahile mal taşıması açısından önemli bir katkıydı. Şöyle ki o tarihlerde Tokat-Samsun arası karayoluyla 40 saat iken Niksar-Ünye arası yalnız 25 saat sürmekteydi. Bu yönleriyle yol Erbaa ve Niksarlıların Ünye limanıyla bağ kurmasına büyük fayda sağlamaktaydı. Bk. İbrahim Serbestoğlu, Bir Taşra Şehrinde Tanzimat ve Modernleşme Canik Sancağı 1863-1865, Mengüceli Yayınları, Malatya 2015, s. 53-55.

${ }^{37}$ Ali Açıkel-Mehmet Mercan, "Niksar Kazasının İdari Durumu ve Nüfus Yapısının Dini ve Etnik Açıdan Analizi (1880-1916)”, Hacettepe Üniversitesi Edebiyat Fakültesi Dergisi, C. 19, S. 2, 2002, s. 237. Canik Sancağı'na bağlı Ünye kazasının Fatsa, Bolaman (Çamaş ile birlikte) ve Karakuş'la birlikte dört nahiyesi arasında 1869'da Niksar da siralanmaktaydı. Nahiye müdürü Ahmed Efendi'ydi. Bk. TVS (Trabzon Vilayet Salnamesi), 1286/1869, s. 46. Bu tarihe gelindiğinde Karadeniz boyunca Trabzon, Samsun, Lazistan, Rize, Arhavi, Giresun, Ünye, Bafra, Tirebolu, Bucak ve Çarşamba'da telgraf merkezleri kurulmuş durumdaydı. Bk. TVS, 1286/1869, s. 61. Ünye kazasına 16, Samsun livasına 34 ve Trabzon vilayet merkezine 82 saat uzaklıkta olan Niksar'1n, 1870-72 senelerinde nüfusu 8191 erkek olarak kaydedilmişti. Bu tarihlerde müstakil kaza olarak anılan Niksar'nn merkezinde 22 mahalle vardı. Köy sayısı 56'ydı. Bk. TVS, 1287/1870, s. 86, 92-93.

${ }^{38}$ Açıkel-Mercan, agm, s. 239.

${ }^{39}$ BOA, İ. DH. (İrade Dahiliye), 668.

${ }^{40}$ BOA, İ. DH. 668/46529, 8 Ocak 1873 (1289.ZA.9).

${ }^{41}$ BOA, İ. DH., 668/46529, 1 May1s 1873 (1290.RA.3).

${ }^{42}$ BOA, İ. DH., 668/46529, 17-18 May1s 1873 (1290.RA.19-20). 
14 Rebiü’l-ahir [1]290/11 Haziran 1873 tarihli yazı ${ }^{43}$, Niksar hattının durumu ile ilgili Sadaretin sorusu üzerine Vekâlet tarafından yazılan bir yazıdır. Yeni bir telgrafhane binası ile hat için gerekli direklerin hazır olduğu gibi bilgileri içermektedir. 1552 adet ve 20 Zilkade [12]89/18 Ocak 1873, 35 adet ve 20 Rebiü'l-evvel [12]90/18 Mayıs 1873 tarihleri ile vekâlete gelen iki fermanla ilgili bu yazıdan anlaşıldığı kadarıyla masraflar ve maaşların mevcut sene bütçesinden düzenlenmesi ve ödenmesi mümkündü. Ancak adı geçen bütçenin içerdiği masraflar ve maaşları ortaya koyan, hazineden verilmesi gereken, defter sureti henüz ulaşmamıştı. Söz konusu hattın inşasına izin verildiği anda ve anılan defter suretinin ulaşması halinde lazım olan eşya Avrupa'ya sipariş olunacaktı: Buna ek olarak telgrafhanede istihdam edilecek memurların seçilerek yola çıkarılması hakkında Vekâlete yetki verilmiş̧i. Burada vekâletten kast edilen Telgraf Nezareti olmalıdır. 1873'te izni çıkan Niksar Telgraf hattının kısa sürede tamamlandığı anlaşılmaktadır (Bk. Harita 1). Bununla beraber Niksar Telgraf merkezinin görevlileri hakkında 1879 tarihine kadar bir bilgiye rastlanmamıştır. Telgrafhanede tek kadro telgraf memurluğu olup bu görevde 1879 'da İsmail Efendi bulunmaktayd1 ${ }^{44}$. İsmail Efendi 1882 senesine kadar bu görevde kalmıştır (Bk. Ek-6).

Niksar-Ünye arasında bir de koruma istasyonu olduğu belgelerden anlaşılmaktadır. Belgeler, Ünye'den Niksar'a bağlı olan telgraf hattı üzerindeki tahaffuzhaneye bağlanan telgraf merkezinde geçici görevli maaşlı memurların maaşlarının geçici bütçeden düzenlenmesini öngörmektedir ${ }^{45}$ Ayrıca, bazen Ünye-Niksar arasında telde kırılmalar meydana gelmektedir. $\mathrm{Bu}$ da iki merkez arasındaki iletişimi zora sokmakta ve zaman zaman aksamalara yol açmaktadır. Örneğin, Posta ve Telgraf Nezareti Meclisi adet 3168 yazı Ünye ve Niksar arası tel kırıklığıyla ilgilidir. Sivas Telgraf ve Posta Baş Müdürlügünden gelen 10 Haziran [1]312/22 Haziran 1896 tarihli ve 54 numaralı telgraf-namede Niksar'la Ünye arasında telde kırıklık meydana geldiği ve kırıklığın üç günden beri düzeltilemediği belirtilmiştir. Kırıklığın bu şekilde devamının 24 saat mesafesi olan hatta büyük sorun yarattığının altı çizilmiştir. Hat boyunca iki çavuş görevli olsa da bunların hatta birbiriyle karşılaşmalarına değin 2-3 gün gerektiği vurgulanmıştır. $\mathrm{Bu}$ nedenle hatta ek olarak iki çavuşun tayiniyle beraber haberleşmenin kolaylaşması ve sağlanması için Niksar ve Tokat arasına bağlanacak hattın direklerinin dikilmesine o havalide bulunan Müşir Şakir Paşa'nın emriyle başlanılacağ sebebiyle gerekli telgraf eşyasının ulaştırılması gereği beyan olunmuş ve talep edilen eşya anbar mevcudundan gönderilmiş olup ancak maaşları 250'şer kuruş olmak üzere iki geçici çavuşun tayin ve görevlendirilmesi konusunda mahalline yetki verilmişse de 500 kuruş maaşa karşılık olmadığı muhasebeden yazılan 5563 numara ve 11 Temmuz [1]312/23 Temmuz 1896 tarihli der-kenarda belirtilmiş olduğundan şu halde çavuşların işe başlama tarihlerinden geçerli olmak üzere söz konusu meblağın geçici bütçeye eklenmesi konusuna izin verilmesi lüzumu bir muhalif oya karşı çoğunluk oyu ile kararlaştırılmıştı (29 Safer 1314/9 Ağustos 1896) ${ }^{46}$. Sadrazamın imzasının bulunduğu konuyla ilgili yazı Niksar ile Ünye arasındaki telgraf hattında görevli iki çavuşun yeterli olmaması nedeniyle hat için ilaveten ve geçici olarak iki çavuşun aylık 250'şer kuruş maaşının göreve başlamalarından itibaren geçici bütçeye eklenerek düzeltilmesi konusunun Telgraf ve Posta nezaretine havalesi hakkında Şura-y1 Devlet Dahiliye Dairesinin mazbatasının arz ve takdim olunduğunu dile getirmektedir (19 Cemaziye'l-evvel [1]314/26 Ekim 1896. Der-kenar da Serkatip Tahsin imzasını taşıyan Sadaret tezkeresi gereğince gereğinin yapılması istenmektedir (27 Cemaziye'l-evvel sene

${ }^{43}$ BOA, İ. DH., 668/46529, 11 Haziran 1873(1290.R.14).

${ }^{44}$ TVS $1296 / 1879$, s. 104-105.

${ }^{45}$ BOA, BEO. (Babıali Evrak Odas1) 88/6580, 14 Ekim 1892 (1310.RA.22).

${ }^{46}$ BOA, ŞD. 1120/6, 7 Ekim 1896 (1314.R.29). Bu belgenin içerisinde Telgraf Nezaretinin mazbatasına ek olarak Dahiliye ve Telgraf Nezaretlerine ait konuyla ilgili tezkerelerde bulunmaktadır. Bu tezkerelerde aynı görüş bir kez daha tekrarlanmaktadır. 
[1]314/3 Kasım 1896) ${ }^{47}$. Söz konusu tarih Erbaa-Tokat hattının kurulduğu tarih olması açısından önemlidir.

1885 senesinde Niksar Telgrafhanesi meydana gelen selden zarar görmüştür. Niksar telgraf merkezinin korunması hakkında harcanmasına gerek duyulan meblağın düzenlenmesi isteğini içeren tezkere Posta ve Telgraf Nezareti Muhasebe Kalemi Adet 86 ile Dahiliye Nezaretine yazılmıştır. 1885 senesi Rumi Mayıs'ın beşinci günü Niksar kasabasında büyük bir yağmur yağmış, kasabanın ortasından geçen nehrin taşmasıyla meydana gelen sel Telgraf ve Posta Merkezini istilâ etmiş ve bu olaydan yola çıkılarak merkezin bu gibi afetten korunması için taş duvar ile etrafinın düzenlenmesi, harap olan yerlerinin tamiri gerektiğinden ve Kaza İdare Meclisinden verilen keşif mazbatası ek olarak gönderilmiş, gerekenin yapılması Kastamonu ve Trabzon Baş Müdüriyetinden gelen 80 numara ve 29 Haziran [1]301/11 Temmuz 1885 tarihli yazıda iletilmiş ve yazı havale edilerek mazbatada istenen duvar ve tamirin keşfi sonucunda 3250 kuruş harcanmasıyla gerçekleştirilebileceği tahmin edilmiş, bütçede karşıllı̆ 1 olmadı ̆̆ 1 gerekçesiyle söz konusu meblağ 1301 senesi tamirat bütçesine eklenerek harcanması için yetki istenmiştir (14 Zilkade [1]302/25 Ağustos $1885^{48}$.

Niksar Telgrafhane binası 1901'de Hükümet Binasına yakın bir yere taşınmıştır. Sadaret Mektubi kaleminden Dâhiliye Nezaretine gönderilen 22 Şaban [1]319/4 Aralık 1901 tarihli yazı Niksar telgrafhanesinin hükümet binasına yakın bir mevkide yeniden inşası hakkındadır. Belgeden anlaşıldığına göre konu çözülmek üzere Dahiliye Nezareti'ne sevk edilmiştir ${ }^{49}$. Umûr-1 Dahiliye Nazırı imzasını taşıyan 25 Cemaziye'l-ahir [1]319/8 Ekim 1901 tarihli ve Mektubi kalemi 3249 sayılı ve sadrazamlığa gönderilen yazıda aktarıldığına göre Niksar Telgrafhanesi Hükümet Dairesi'nin uzağındaydı. Eşraftan Mahir ve Vehbi Efendilerin bağışladığı 5000 kuruş kıymetindeki arsa üzerine 5900 kuruş harcanarak yeniden bir telgrafhane inşa edilmişti. Bu nedenle eski telgrafhanenin 6000 kuruşla açık artırmaya çıkarılması ve talibine satılması Sivas Telgraf ve Posta Baş Müdürlüğüne işaret edilmişti. Adı geçen telgrafhanenin bu suretle satılması ve böylece elde edilecek gelirden başka masraf talep edilmemesi ve tapusu devlet namına düzenlenmesi yoluyla yeni bir telgrafhane inşası uygun görülmüş ve konunun Şura-yı Devlet tarafından görüşülmesinin Sadrazam tarafından kabul gördüğü dile getirilmiştir ${ }^{50}$. Belgeden anlaşıldığına göre Posta ve Telgraf Nezareti ilgili konuda 29 Ağustos [1]317/11 Eylül 1901 tarihli ve 347 numaralı tezkerede yetki istemekteydi. Bu yazışmalar bu yetki isteğine bir cevap niteliğindedir.

\section{V.Niksar-Erbaa-Tokat Arası Telgraf Hattı Kurulması Çabaları}

1874 yılına gelindiğinde Niksar-Ünye, Tokat-Sivas ve Amasya-Zile hatları kurulmuş durumdaydı (Bk. Harita 1). Bununla birlikte 1880 'de Tokat'a bağlanacak olan Niksar ve Erbaa'nın burayla doğrudan bir telgraf bağlantısı yoktu.

\footnotetext{
${ }^{47}$ BOA, BEO, 863/64655, 7 Kasim 1896 (1314.C.1).

${ }^{48}$ BOA, ŞD. 2469/13, 5 Nisan 1886 (1303.R.1).

${ }^{49}$ BOA, BEO. 1757/131732, 6 Aralık 1901(1319.Ş.24).

${ }^{50}$ BOA, ŞD. 2713, 7 Ekim 1902 (1320.B.4).
} 


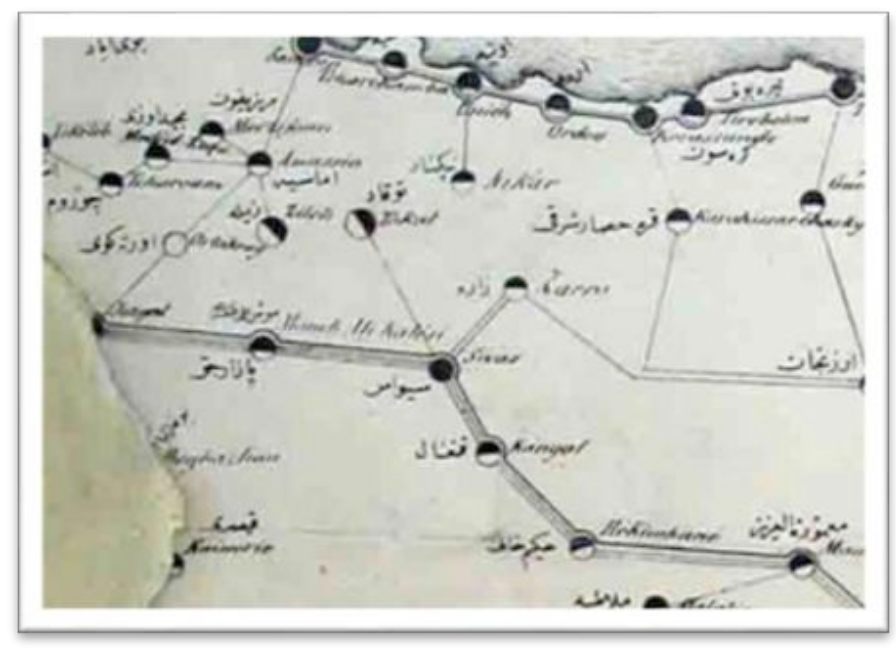

Harita 1. Carte Telegraphique de L'empire Ottoman 1874

(Kaynak: midafternoon.com, 23.08.2017, 22:43)

Erbaa, Tokat ili sınırları içerisinde Yeşilırmak havzası üzerinde kurulu bir ilçedir. Kuzeyden Ordu ve Samsun illeri, batıdan Amasya ili ve Tokat Turhal ilçesi, güneyinden Tokat Merkez ve doğusundan Tokat Niksar ilçeleriyle çevrilidir ${ }^{51}$. Uzun zaman Erek olarak bilinen bölgeye, Tanzimat döneminde Nevahi-i Erbaa adı verilmiştir. Bu adın verilmesinde Erek, Karayaka, Sonisa ve Taşabat adı verilen dört nahiyenin bir merkezde birleştirilmesi etkili olmuştur. Daha sonra Nevahi kelimesi terk edilerek bölge sadece Erbaa olarak anılmıştır. 1840 tarihinde yapılan servet sayımlarına ait defterlerde bölge, "Kaza-i Erbaa" olarak zikredilmiştir. Erbaa'nın kaza merkezi Erek olarak kayda geçmiştir ${ }^{52}$. 1848'de Sivas'a bağlı Erek, Taşabad, Sonisa ve Karayaka kazaları Kaza-i Erbaa adıyla bir müdür bünyesinde birleştirilmiş ve müdürlük görevine Tokatlı Ali Ağa diye biri getirilmiştir ${ }^{53}$. 1872'de Amasya'ya bağlı olan Erbaa $1880^{\prime}$ de Tokat'a bağlanmıştır ${ }^{54}$. Erbaa Kazasında 1890 senesinde Erek, Karaağaç, Sepetli, Sonisa, Alathiyan, Ziğdi, Dereli nahiyelerinde 155 köy bulunmaktaydı ${ }^{55}$. 1892 'de kaza nüfusu 40900 olup 30450'si Müslüman'd1. Kazada farklı mezheplerden ve çoğunluğu Gregoryen olmak üzere 7837 Ermeni ve ayrıca 2613 Rum nüfus vard1 ${ }^{56}$.

\section{V.I.Niksar-Erbaa-Tokat Hattı İçin İlk Girişimler}

İlk olarak 1880 'de tasarlanan Niksar-Erbaa-Tokat telgraf kablosu 1887 senesinde Tokat Mutasarrıflığının girişimleriyle yeniden ve daha etkili bir biçimde gündeme taşınmıştır. Tokat Mutasarrıflığından 239 numarayla Sivas Vilayetine gönderilen 13 Zilkade [1]304/4 Ağustos 1887 tarihli yazı, Erbaa'da telgraf hattı bulunmaması ve Niksar'ın sancak merkezi Tokat'la doğrudan bir hatta sahip olmamasına ilişkindir. Mutasarrıflığın yazısında ilk olarak hükümet işlemleri, ticaretin kolaylaştırılması ve çoğalmasına kendi başına araç olan telgraf hattının her

\footnotetext{
${ }^{51}$ Yavuz Özyürek, 16146 Numaralı Temettüat Defterine Göre Erbaa Kazası'na Bă̆ll Karayaka Nahiyesi'nin Sosyo-Ekonomik Yapısı, (Çankırı Karatekin Üniversitesi Sosyal Bilimler Enstitüsü Yayımlanmamış Yüksek Lisans Tezi), Çankırı 2012, s. 21.

52 Emine Mehveş Erçin, 19. Yüzyılda Erbaa Kazası'nın Sosyo-Ekonomik Yapısı, (İstanbul Üniversitesi Sosyal Bilimler Enstitüsü Yayımlanmamış Yüksek Lisans Tezi), İstanbul 2005, s. 4-5.

${ }^{53}$ İsmail Kıvrım, Taşova-Erbaa Yerleşme-Nüfus Ekonomi (15-16. Yüzyıl), Kitabevi Yayını, İstanbul 2014, s. 36.

54 Mahmut Hazım Şahin, Türkiye'de Yeri Değiştirilen Şehirlere Bir Örnek: Erbaa/Tokat, (Ondokuzmayıs Üniversitesi Sosyal Bilimler Enstitüsü Yayımlanmamış Yüksek Lisans Tezi), Samsun 2012, s. 27.

${ }^{55}$ Esat Aktaş, agt, s. 84.

${ }^{56}$ Esat Aktaş, agt, s. 92.
} 
yerde var olmasının önemi üzerinde durulmuştur. Bu önemine rağmen o ana kadar Erbaa kazasının merkezi olan Erek kasabasına bir telgraf hattı bağlanmaması konusu dile getirilmiştir. Ayrıca Niksar kasabası ile Tokat arasında doğrudan bir hat olmamasından dolayı Niksar'dan mutasarrıflık merkezine çekilen telgraf-namelerin çok sayıda ve uzak merkezlere uğramasından ötürü epey gün sonra Tokat'a ulaştı̆̆ına işaret edilmiştir. Yazıda, iki kazanın bu durumlarından dolayı mutasarrıflık sınırlarında telgraftan gereği gibi yararlanılamadığı, birçok hükümet işleminin ve ticâri faaliyetin ertelenmek ya da gecikmek zorunda kaldığının altı çizilmiştir. Mutasarrıflık söz konusu merkezler ile Tokat arasında kurulacak telgraf bağlantısının yararlı bir iş olacağını da ifade etmiş̧tir. Mutasarrıflığın belirttiğine göre yakın zamanda bu hat için müfettiş gelmiştir. Hat müfettişi ile konu görüşülmüştür. Görüşmelere göre hat Tokat-Çilkoru ${ }^{57}$-Erbaa-Niksar güzergâhında çekilecekti (Bk. Harita 2). Tokat'tan Çilkoru sınırına kadar altı saat mesafe için 480, Çilkoru'dan Erbaa'ya ve Erbaa'dan Niksar'a kadar mesafe için 560'ar direk gerekecekti. Tokat-Çilkoru arasındaki direklerin temini ve dikilmesi için gerekli masraf Tokat'a, Çilkoru'dan Erbaa'ya kadar direk masrafı Erbaa'ya ait olacaktı. Erbaa aynı zamanda üç odalı bir telgrafhane inşasını da üstlenecekti. Erbaa-Niksar arasında dikilecek direklerin masrafını Niksar karşılayacaktı. Tel, porselen ve makine gibi araç-gereçlerin temini Telgraf Nezaretine ait olacaktı. Direk bedeliyle masraflardan Niksar hesabına 3000; Erbaa'ya telgrafhane masrafiyla birlikte 6000 ve Tokat'a 2500 kuruş düşmekteydi. Bunların yardım yoluyla karşılanması tahhü̈t altına aldırılarak gerekli olan mazbatasının ulaştııılmasının Erbaa ve Niksar kaymakamlıklarına yazılı olarak bildirilmesine karar verilerek keyfiyet o şekilde mahallerine bildirilmişti. Cevap olarak gelen mazbatalarda daha önce adı geçen kazalara birer telgraf hattının bağlanması çok gerekli olduğunun belirtilmesiyle beraber isabet eden masrafların yardım yoluyla karşılanacağ 1 taahhüt edilmiş ve Erbaa'ya bu şekilde bir telgrafhane inşasına da girişilmiş olduğu bildirilmişti. Tokat'tan Çilkoru'ya kadar ortaya çıkacak direk temini ve dikme masrafı Tokat ahalisi tarafından taahhüt edildiğinden şu müsait günlerde inşaat emrinin verilmesi; tel, porselen ve makine gibi edevâtın gönderilmesi, bir memurun da tayini konularının çözülmesi hususunda durumun Bâbıali’ye iletilmesi belirtilmekteydi ${ }^{58}$.

Sivas Vilayet İdare Meclisine 518 numarayla gelen, oradan Posta ve Telgraf Baş Müdürlüğüne ve Valinin bilgisine sunulan 26 Temmuz [1]303/7 Ağustos 1887 tarihli ferman Osmanlı hükümet organları tarafından Tokat İdare Meclisinin mazbatasının değerlendirildiğini ortaya koymaktadır. Ferman Osmanlı merkez yönetiminin söz konusu hatta çok soğuk bakmadığını ancak hemen yapılmasını da mümkün görmediğini göstermektedir. Belge ayrıca, Tokat'tan Erbaa'ya uğratılarak Niksar'a bir telgraf hattı çekildiği takdirde sahil hatlarıyla büyük/ana hat arasında buradan da bir irtibat noktası kazanılarak iyi bir hizmet gerçekleşeceğine olan inancı içermektedir. Ne var ki daha önce Telgraf ve Posta Nezaretine yapılan yazılı başvuruya cevaben adı geçen hattın bağlanmasının epeyce harcama gerektirmesi, o sene için devletin şiddetli tasarruf önlemlerine başvurması nedeniyle hattan şimdilik vazgeçilmesi önerilmektedir (29 Temmuz [1]303/10 Ağustos 1887) ${ }^{59}$.

$\mathrm{Bu}$ erteleme kararı Sivas Vilayetindeki resmi organları yıldırmamış gözükmektedir. Zira söz konusu hattın kurulması için Kasım 1887 tarihinde Vilayet İstanbul'la yeniden yazışmalara ağırlık vermiştir. Sivas Vilayeti İdare Meclisinin Dahiliye Nezaretine yolladığ 122 Teşrin-i Evvel [1]303/3 Kasım 1887 tarihli mazbatada Erbaa ve Niksar kazalarının aynı yönde olduğu ve Niksar kazasında telgraf merkezi varsa da teli, sahilde bulunan Ünye kazasından bağlanmış olduğu için o tarihlerde bağlı bulunduğu Tokat Sancağı Mutasarıflığıyla haberleşmesinin

${ }^{57}$ Günümüzdeki adı Gökdere olup Tokat Merkez ilçesine bağlı bir köydür.

${ }^{58}$ BOA, ȘD. 2530/2, 23 Şubat 1888 (1305.C.10).

${ }^{59}$ BOA, ŞD. 2530/2, 23 Şubat 1888 (1305.C.10). 
Ünye, Samsun ve daha birçok merkezi dolaşarak cereyan etmekte olduğu bir kez daha hatırlatılmıştır. Erbaa kazası önemli bir ticaret mevkii olduğu halde orada henüz bir telgraf merkezi açılmadığından dolayı Tokat'tan Erbaa'ya ve Erbaa'dan Niksar'a kadar bir tel bağlandığı takdirde hem livayla Niksar ve Erbaa arasında doğrudan doğruya haberleşmenin mümkün olacağı hem de Der-saâdet haberleşmesi için alternatif bir kanal açılacağ vurgulanmıştır. Direk masrafını bir kez daha yazan mazbata bu telin bağlanmasıyla Erbaa'da işlerin kolaylaşacağ 1 ve çok sayıda iyiliklere vesile olacağ 1 konusunda incelemelerde bulunan müfettişin olurunu hatırlatmakta ve telgraf hattı konusundaki isteği tekrarlamaktadır ${ }^{60}$..

Erbaa ve Niksar'ın Tokat'la bağlanması için merkezle yazışmalar sürerken aynı tarihlerde hat için fizibilite çalışmalarının başlatıldığı görülmektedir. Dâhiliye Nezaretinden gelen 197 numara ve 1 Kanun-1 Evvel 1303/13 Aralık 1887 tarihli tezkere ekinde Fen Kaleminden düzenlenen keşif pusulası bu durumu kanıtlamaktadır. Pusuladan anlaşıldığı kadarıyla bu hat için tel, izolatör ve diğer araç-gereç bedeli 11139 Frank 40 santim $^{61}$, bu eşyanın mahalline sevki için nakliye masrafi 2152 kuruş ${ }^{62}$ ve hattın tamiri, basılı evrakı ve diğer giderler için 593 Frank $^{63}$ ile 6000 kuruşa $^{64}$ ulaşacağ 1 ; memurlar, çavuş ve hademe maaşıyla kırtasiye masrafları olarak aylık 2080 kuruşun $^{65}$ tahsisi gerekeceği anlaşılmaktadır. Belge ekinde yer alan harita (Bk. Harita 2) ise gerekli malzemelerin ve hattın güzerhahını içermektedir (23 Kanun-i Evvel [1]303/4 Ocak 1888) ${ }^{66}$

${ }^{60}$ BOA, ŞD. 2530/2, 23 Şubat 1888 (1305.C.10).

61 Posta ve Telgraf Nezareti Muhasebe Kaleminden 330 adetle çıkan yazıda Erbaa-Niksar-Tokat arasında bağlanacak telgraf hattının birleştirilmesi ve açılması için gerekli eşyanın keşif pusulası yer almaktadır (21 Kanûn-1 Evvel sene [1]303/2 Ocak 1888) ${ }^{61}$. Bu pusulaya göre hat için temin edilecek eşya içerisinde çeşitli kalınlıkta ve uzunlukta teller, izolatör, Mors makinası, pil, nişadır tuzu, çavuş takımı, bant kağıdı ve kalay gibi makine ve teçhizat yer almaktaydı. Bunların 11139 Frank 40 santim tutarındaydı. Bu ücrete \% 0,5 sigorta ücreti ve \%8 gümrük vergisi de dahildi.

${ }^{62}$ Pusulada yer alan bilgilere göre eşyanın temin edilmesi dışında nakliyesi de önemli bir yekun tutmaktaydı. Adı geçen eşya 4000 kg. miktarındaydı ve İstanbul'a 154 saat uzaklıktaki Ünye'ye deniz yoluyla taşınması 616 kuruş; oradan da 22 saat mesafedeki Niksar'a taşınması 1056 kuruş, bütün hat boyuna kara yoluyla taşınması 480 kuruş tutmaktaydı. Bütün nakliye masrafı olarak 2152 kuruş masraf öngörülmekteydi.

${ }^{63} 593$ Frank her sene yenilenmesi ve Avrupa'dan çekilmesi gereken eșya için ayrılan miktardır.

${ }^{64} 6000$ kuruş her sene hattın tamiri için harcanması düşünülen 5600 kuruş ile senelik matbu evrak giderine ayrılan 400 kuruşun toplamıdi.

${ }^{65}$ İnşaat masrafları ve direkler ahaliye yüklenmiştir. Bunun dışındaki çeşitli küçük masraflar içerisinde bir müdür, dört çavuş, bir kavass gibi görevlilerin maaşları ile kırtasiye ve diğer masrafların aylık 2080 kuruş tutacağı tahmin edilmiştir. Ayda müdür aylığı 600 kuruş, her biri 300 kuruş olmak üzere 4 çavuşun aylığı toplam 1200 kuruş, bir kavassın aylığıysa 200 kuruş olarak hesaplanmıştı. Kırtasiye ve diğer küçük masrafların 80 kuruş olacağ düşünülmüştü.

${ }^{66}$ BOA, ŞD. 2530/2, 23 Şubat 1888 (1305.C.10). 


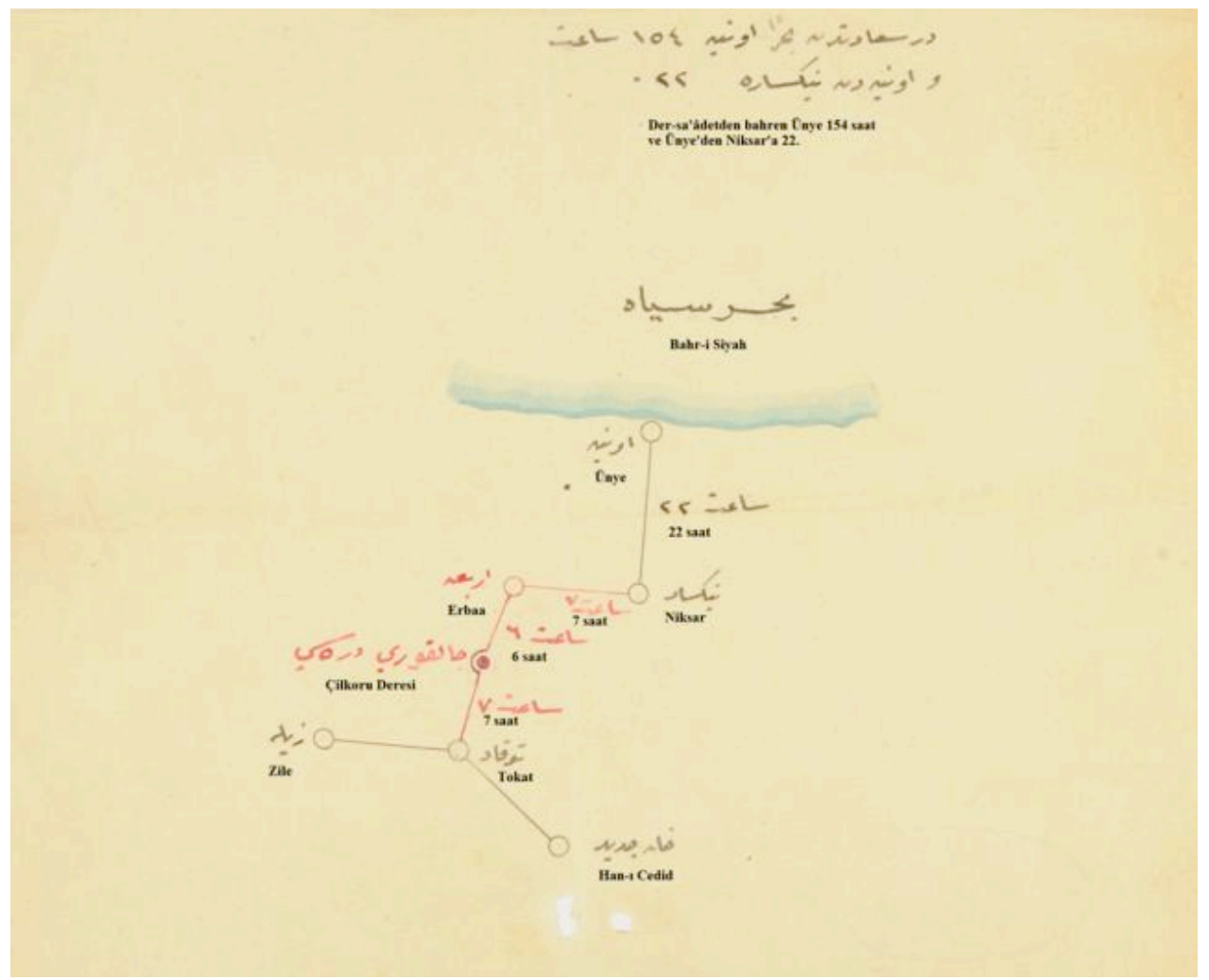

\section{Harita 2. Niksar-Erbaa-Tokat Hattı İçin Eşya Naklinin Yapılacağı Güzergah}

1887 senesindeki ilk girişimlerin İstanbul'da pek de olumlu karşıllk bulmadığı görülmektedir. Umur-1 Dahiliye Nazırı imzası taşıyan Bâbıali Dahiliye Dairesi Mektûbî Kaleminden çıkan 197 adet ve 28 Rebiü'l Evvel Sene [1]305/1 Kânun-1 Evvel Sene [1]303 /14 Aralık 1887 tarihli tezkere Telgraf ve Posta Nezaretine yazılmıştır. Bu yazıda Tokat merkezinden Erbaa'ya ve Erbaa'dan Niksar'a kadar bir telgraf hattı bağlanması işi için büyük harcama gerektiğinden dolayı şimdilik bundan vazgeçildiği bilgisi verilmiştir ${ }^{67}$. Bu yazıya cevaben Telgraf ve Posta Nazırı imzasını taşıyan tezkere 26 Rebiü'l-ahir [1]305/11 Ocak 1888 tarihlidir. Tezkerede söz konusu hat için karşılanması gerekli masraf için ilgili sene bütçesinde karşılık olmadığı, bütçede tasarruf sağlanması beklenirken ek yük getirmenin yanlış olacağı, bu çeşit hatların inşasına elde edilecek gelirlerin yetmeyeceği, bu nedenle hattın inşasının tehir edilmesinin zaruri olduğu dile getirilmiştir. Bu tezkere ve ekleri Nezaretin görüşünün karara bağlanması için Şura-yı Devlete de havale edilmiştir (7 Kanun-i Sanî sene [1]303/19 Ocak $1888)^{68}$.

Dahiliye Nezareti ve bu nezarete bağlı Telgraf ve Posta Nezaretinin olumsuz görüşlerine karşı Tokat-Erbaa ve Niksar arasında telgraf bağlantısının kurulmasına yönelik girişimler 1888 yılında da devam etmiştir. Tokat Mutasarrıflığından Sivas Vilayetine gönderilen 568 numaralı yazıda, Erbaa kazasının büyüklüğü, nüfusunun çokluğu, arazisinin verimi gibi nedenleri öne sürüp telgraf hattının açılması konusunda 1srar edilmiştir. Geliri giderini karşılamasa bile bu açığın tüccar tarafından üstlenileceği belirtilmiştir. Yazıdan anlaşıldığı kadarıyla Erbaalı tüccar

\footnotetext{
${ }^{67}$ BOA, ȘD. 2530/2, 23 Şubat 1888 (1305.C.10).

${ }^{68}$ BOA, ŞD, 2530/2, 23 Şubat 1888 (1305.C.10).
} 
ellerinde bulunan 10000 kuruşluk istikraz-1 dahili/iç borç kuponlarını bu iş için ayırmıştır (17 Cemaziye'l-evvel [1]306/19 Ocak 1889) ${ }^{69}$.

Mutasarrıflığın bu yazısı 21 Ocak 1889'da Vilayet İdare Meclisine, oradan 30 Ocak 1889 'da konuyla ilgili mütalaaları alınmak üzere Sivas Telgraf ve Posta Müfettişliğine havale edilmiştir. Son olarak 8 Şubat 1889 'da konunun İstanbul'a sorulması uygun bulunmuştur. Vilayet İdare Meclisi konuyla ilgili düzenlenen mazbatanın Dâhiliye Nezaretine takdimi ve telgraf aracılığıyla Posta ve Telgraf Nezareti'ne gönderilmesi kararını almıştır ${ }^{70}$.

Bu karar doğrultusunda Sivas Vilayeti İdare Meclisi 26 Şevval [1]306/25 Haziran 1889 tarihinde Dahiliye Nezareti'ne gönderdiği yazıda Tokat'tan Erbaa'ya ve Erbaa'dan Niksar'a bir telgraf hattı bağlanması talebini dile getirmiştir. Mazbata 1887-1888'deki yazışmaların bir özetini verdikten sonra Erbaa'ya bir hat çekilmesini zorunlu kılan ve kazayı belirli konularda öne çıkaran faktörleri sıralamıştır. Bu meyanda Nezareti etkilemek maksadıyla mazbatada (Erbaa) kazasının nüfusunun çokluğu, arazisinin bol ve verimli olması ve her çeşit mahsulün yetiştirilmesi, mahsulün büyük bir kısmının dışarıya gönderilmesi, bu açıdan Erbaa'nın Samsun, Amasya, Tokat ve diğer başka mahallerle alakadar olması, mahsulün fiyatının belirlenmesi, nakliyesi ve benzer hususlarda aracısız haberleşmeye mecbur olunması, reji idaresinin de çok sayıda yazışma ve haberleşmesinin olmasının önemine dikkat çekilmiştir. Aynı yazıda Erbaa telgrafhanesinin geliri giderinden fazla olmasa bile oluşacak açığın şimdiden tüccarlar tarafından taahhüt edildiği, telin nakli ve diğer işlerde harcanmak üzere ellerinde bulunan 10000 kuruşluk istikraz-1 dahili kuponlarını bu iş için vermeye hazır oldukları belirtilmekteydi. Erbaa'nın bazı özellikleri, özellikle köy sayısı abartılmak suretiyle bu yönden de Nezaret etki altında bırakılmaya çalışılmaktaydı. Erbaa kazasının 400 köy ve verimli araziyi içinde bulundurmasından dolayı ticaret açısından önemli bir yer teşkil ettiği, buna rağmen hızlı bir haberleşme aracı olan telgraf hattına sahip olmadığı için hiçbir yere, bilhassa gerekli mahallere zamanında haber gönderemediğinden emsallerine kıyasla büyük ölçüde menfaat kaybına uğradığı, bununla birlikte çeșitli eserler, zahire satıșında liva ve civarıyla haberleşmede zorluk çektiğinin altı çizilmekteydi. Tokat'tan Erbaa'ya hat çekilmesi konusunda Nezaretten 1srarla olumlu bir cevap umulmaktaydı (26 Şevval [1]306/25 Haziran $1889^{71}$. Bununla birlikte Bâbıali Dahiliye Dairesi Mektubi Kaleminin 16 Adet ile Telgraf ve Posta Nezaretine yazdığı yazıda daha önceden yapılan yazışmalara gönderme yapmakta ve konuyu geçiştirmekteydi (29 Teşrin-i Evvel [1]305/10 Kasım 1889) ${ }^{72}$. Niksar-Erbaa-Tokat hattının ekonomik gerekçelerle askıda bırakılması 1889'da Erbaalıları yalnız kazalarından Erbaa'ya bir hat çekme talebine yöneltmiş gözükmektedir.

\section{V.II.Yalnız Erbaa Hattı İçin Girişimler}

Şura-yı Devlete gönderilen belgeler içerisinde yer alan pusula zaman içerisinde NiksarErbaa-Tokat hattının maliyet nedeniyle sürekli ertelenmesi nedeniyle daha önce hazırlanan pusuladan farklı ve yalnız Erbaa-Tokat arasını içeren bir hat düşüncesinin ortaya çıktığını göstermektedir. Bu yeni pusulada telgrafhane binası inşası için konulan 10000 kuruş dışarıda tutulduğunda, 4693 Frank 60 santim, 8458 kuruş masraf çıkarıldığı görülmektedir. Bu açıdan bakıldığında yalnız Erbaa-Tokat hattının gündeme gelmesiyle masrafın diğer hatta göre yarıdan daha fazla azaldığı anlaşılmaktadır. Posta ve Telgraf Nezareti Mühendis ve Muhasebe Kaleminde hazırlanan keşif defterinde yer alan söz konusu ikinci pusulada Tokat'a 65 km. uzaklıkta bulunan Erbaa kasabasına kadar uzatılacak telgraf hattı için gerekli eşyaların ve diğer

${ }^{69}$ BOA, ŞD. 1790/27, 11 Mart 1895 (1312.N.14).

${ }^{70}$ BOA, ŞD. 1790/27, 11 Mart 1895 (1312.N.14).

${ }^{71}$ BOA, ŞD. 1790/27, 11 Mart 1895 (1312.N.14).

${ }^{72}$ BOA, ŞD. 1790/27, 11 Mart 1895 (1312.N.14). 
giderlerin dökümü yapılmıştır (22 Temmuz [1]305/3 Ağustos 1889) ${ }^{73}$. Posta ve Telgraf Nezareti Meclisi 592 adetli tezkerede Mühendis kaleminin hazırladığı pusulanın görüşüldüğü anlaşılmaktadır. Tezkerede masrafların dökümü yapıldıktan sonra her ne kadar bir defaya özgü harcamaların ahali tarafından karşılansa bile daimi masrafların bütçeye ek yük getireceği, bu nedenle söz konusu merkezin açılması hususunda Nezaretin bu konuya dikkat etmesi gerektiği konusunda uyarı yapılmıştır (27 Muharrem [1]307/23 Eylül 1889) ${ }^{74}$. Bu durum Erbaa'nın yalnız başına bir telgraf talebinin de İstanbul'da bütçe yetersizliği nedeniyle geri çevrildiğini ve ertelendiğini kanıtlamaktadır.

Erbaa-Tokat hattı için hazırlanan ikinci pusulada masrafların iki ana kalemde toplandığı görülmektedir. Bunlardan ilki hat için bir defalık yapılacak harcamalardır. Bir kerelik harcamaların ilk dilimini telgrafhane ve hat için gerekli olan ve dışarıdan ithal edilecek malzemeler oluşturmaktadır. Bunların toplamı temin ücreti ve gümrük resmi de dahil olmak üzere 4401 Frank 60 santim tutarındadır.

Bir Kerelik Masraflar 1-Talgrafhane ve Hat İçin Gerekli Malzemeler

\begin{tabular}{|c|c|c|c|c|}
\hline Cinsi & Toplam Miktar & Birim ücreti & Frank & Santim \\
\hline $4 \mathrm{~mm}$.lik demir tel & $6500 \mathrm{~kg}$ & 0,28 Frank & 1820 & 0 \\
\hline 2 mm.lik demir tel & $30 \mathrm{~kg}$. & 0,40 Frank & 12 & 0 \\
\hline Lehim & $30 \mathrm{~kg}$. & 2,50 Fran & 70 & 0 \\
\hline Nişadır tuzu & $8 \mathrm{~kg}$. & 1,20 Frank & 9 & 60 \\
\hline Band kağıdı & $20 \mathrm{~kg}$. & 1 Frank & 20 & 0 \\
\hline Küçük Model Osmanlı izolatörü & 975 adet & 1,10 Frank & 1072 & 50 \\
\hline Mükemmel Mors Makinesi & 2 adet & 380 Frank & 760 & 0 \\
\hline Laklanşe pil takımı & 40 adet & 3 Frank & 120 & 0 \\
\hline Çavuş takımı & 2 adet & 65 Frank & 130 & 0 \\
\hline Hamız & 3 şişe & 70 Frank & 21 & 0 \\
\hline İnce lastikli tel & $30 \mathrm{mt}$. & 0,25 Frank & 7 & 50 \\
\hline Kalın lastikli tel & $15 \mathrm{mt}$. & 0,6 & 9 & 0 \\
\hline \multicolumn{3}{|c|}{$\% 0,5$ temin ücreti } & 20 & 0 \\
\hline \multicolumn{3}{|c|}{$\% 8$ gümrük resmi } & 325 & 0 \\
\hline \multicolumn{3}{|c|}{ Toplam } & 4401 & 60 \\
\hline
\end{tabular}

Bir kerelik masraflar içerisinde ikinci dilimi söz konusu malzemenin nakli ve telgraf merkezi için yapılacak harcamalar oluşturmaktadır. Buradaki rakamın 12118 kuruş gibi yüksek bir maliyete sahip olması büyük olasılıkla tüccarın üstlendiği telgrafhane inşası masrafının da rakama dahil edilmesiyle ilgilidir. Bu pusulada dikkat çeken bir durum da önceki pusulada eşya nakli için Ünye limanı seçilirken bu defa eşyaların Samsun limanından nakledilecek olmasidir.

\footnotetext{
${ }^{73}$ BOA, SD. 1790/27, 11 Mart 1895 (1312.N.14).

${ }^{74}$ BOA, ŞD. 1790/27, 11 Mart 1895 (1312.N.14).
} 
Murat HANILÇE

Bir Kerelik Masraflar 2-

Telgrafhane ve hat için gerekli Eşyanın Nakli ve Telgraf Merkezi İçin Yapılacak Harcamalar

\begin{tabular}{lll}
\hline İş & Kuruş & Para \\
\hline $\begin{array}{l}\text { 8100 kg. eşyanın İstanbul'dan Samsun İskelesi'ne kadar deniz yoluyla } \\
\text { nakliyesi }\end{array}$ & 1118 & 0 \\
Telgraf merkezi inşâsı & 10000 & 0 \\
Mefruşat masrafı & 1000 & 0 \\
\hline Toplam & 12118 & 0 \\
\hline
\end{tabular}

Pusulanın ortaya koyduğu masrafların daimi ve senelik masraflarında da iki kaleme rastlamak mümkündür. İlk kalem çeşitli giderler başlığını taşımaktadır. Bu giderler içerisinde senelik yenilenmesi gerekli malzeme, hattın yıllık tamiratı, küçük masraflar ve basılı evrak gideri toplamda 292 Frank ve 5040 kuruş olarak tahmin edilmiştir.

Daimi ve Senelik Masraflar 1-Çeşitli Giderler

HISTORY

STUDIES

81

\begin{tabular}{|c|c|c|}
\hline Masrafın çeşidi & Frank & Kuruş \\
\hline $\begin{array}{l}\text { Senelik yenilenmesi gerekli olan ve Avrupa'dan ithal edilecek eşya } \\
\text { pahası }\end{array}$ & 292 & 0 \\
\hline Hattın senelik tamiratı & & 3640 \\
\hline Merkezin senelik küçük masrafları & & 1000 \\
\hline Merkezin senelik basılı evrakı & & 400 \\
\hline Toplam & 292 & 5040 \\
\hline
\end{tabular}

Daimi ve senelik masrafların ikinci kalemi telgrafhanede görevlendirilecek personelin maaşını içermektedir. Buna göre telgrafhanede bir memur, iki çavuş ve bir muvassıl olmak üzere toplamda dört personel istihdam edilecekti ve bunların aylık maaş toplamı 1300 kuruş tutmaktaydı. Bu rakam bir seneye vurulduğunda 15600 kuruşa ulaşıyordu. 5040 kuruşluk birinci kalem ve 15600 kuruşluk ikinci kalemin toplamı 20640 kuruşu aşıyor ve merkezi bu hattan vazgeçiren başlica neden de bu oluyordu.

Daimi ve Senelik Masraflar 2-Maaşlar

\begin{tabular}{llll}
\hline Telgrafhanede istihdam edilecek görevliler & Adet & Maaş & Aylık toplam maaş \\
\hline Memur & 1 & 500 & 500 \\
Çavuş & 2 & 300 & 600 \\
Muvassıl & 1 & 200 & 200 \\
Toplam & 4 & & 1300 \\
Senede ödenecek toplam maaş & & & 15600 \\
\hline
\end{tabular}

Hükümetin Erbaalıların telgraf talebinde 1890 senesinde halkın üstlendiği meblağı garanti altına alma çabası da gözden kaçmamaktadır. Mutasarrıfa yazılan 24 Receb [1]307/16 Mart 1890 tarihli başka bir tezkerede Tokat'tan Erbaa'ya ve Erbaa'dan Niksar'a kadar telgraf hattı bağlanması hakkında önceden meydana gelen yazışmaya cevaben gelen 18 Kanun-1 Evvel [1]305/30 Aralık 1889 tarih ve 441 numaralı emirnamede bu durum açıkça görülmektedir. Emirnamede hat için gerekli nakdin bütçe içerisinde karşıllı̆ı bulunmadığının altı çizilirken, hat için yardımda bulunacak Erbaalı tüccarların isimlerini içeren bir defter gönderilmesi istenmektedir. Defterde yapılacak yardımın Frank ya da kuruş cinsinden ayrımının net olarak belirtilmesinin önemine işaret edilmektedir Ayrıca Niksar hattı üzerinde durmanın gereği 
olmadığ belirtilmiştir $^{75}$. Bu belge Niksar hattının 1890'a gelindiğinde gündemden çıkarılıp Erbaa için farklı alternatiflerin denendiğini delillendirmesi bakımından önemlidir. Bu hususta başka bir delil Sivas Vilayetinden Şura-yı Devlet'e gönderilen tezkeredir. Sivas Vilayeti Mektûbî Kaleminden çıkan ve 10 numarayla Şûrâ-yı Devlet'e yazılan tezkere Erbaa kazasından Niksar yoluyla Tokat'a açılması tasarlanmış olan telgraf hattı için adı geçen hattın yalnız Erbaa'dan Tokat'a kadar bağlanması durumunda gerçekleşeceğinin Tokat Mutasarrıflı̆̆ tarafindan anlaşıldığını ve hazırlıkların ona göre yapıldığını belirtmektedir. Bu konuda Mutasarrıflığın hazırladığı yeni mazbata ve eklerinin yollandığını söylemektedir (5 Zilhicce [1]307/23 Temmuz 1890) ${ }^{76}$. Dahiliye Nezaretinden Sadarete gönderilen 28 Muharrem [1]308/13 Eylül 1890 tarihli tezkereden Erbaa kasabasının İslam ve Hıristiyan ahalisi vekillerinin 11 A ğustos [1]306/23 Ağustos 1890 tarihinde Tokat-Erbaa hattı konusunda isteklerini tekrar bildirip bu konuda Sadaretin görüşünü sordukları anlaşılmaktadır ${ }^{77}$.

\section{V.III. Hat İçin Devreye Asker Makamların Girmesi}

Erbaa'nın 1890'da tek başına bir hat açtırma teşebbüsünün de atıl kaldığı görülmektedir. Bununla birlikte 1892 'de büyük olasılıkla Karadeniz'in iç bölgelerinde güvenlik nedeniyle bir kısım merkezlere hat açılması gündeme geldiğinde söz konusu hatlar içerisinde tekrar NiksarErbaa-Tokat hattı gündeme gelmiştir. Umum Erkan-1 Harbiye Dairesi Dördüncü Şubeye 24 Rebiü'l-evvel (1)310/16 Ekim 1892 tarihinde Serasker tarafindan yollanan yazı Amasya sancağında Ladik, Havza, Vezirköprü ve Gümüşhacıköy; Tokat sancağına bağlı Erbaa kaza merkezlerinde telgraf hattı kurulmasına ilişkindir ${ }^{78}$. Söz konusu yazıda adı geçen yerlerde birer telgraf hattı açılması için daha önce masraflarının mahallince taahhüt altına alındığı dile getirilmektedir. Aynı yazıda bu konuda hükümet ve idare organları arasında çok sayıda haberleşme gerçekleştirildiği ve Erbaa kazasında ahalinin kendi imkânlarıyla yeni ve eksiksiz bir telgrafhane inşa ettiğinin altı çizilmektedir. Yazı bu bilgileri sıraladıktan sonra hem yukarıda adı geçen yerlere hem de Sivas'ın Kangal köyüyle Şiran, Kelkit ve Divriği kazalarına; A ̆ğın nahiyesine birer telgraf hattının çekilmesinin ve Niksar kazası telgrafının da Tokat'a bağlanmasının önemli olduğundan Müşiriyetin bu hatların açılmasını önemli gördüğüne işaret etmiştir ${ }^{79}$. Posta ve Telgraf Nezareti'ne konuyla ilgili gönderilen tezkerede bu hatların açılmasının askeri haberleşme için gerekli olacağı dile getirilmiştir ${ }^{80}$.

Askeri makamlar konuya el atmış olsa da Posta ve Telgraf idaresinin bu hatları ertelemekteki ekonomik gerekçeler varlığını sürdürmekteydi. Burada idare, bir defalık masraflardan ziyade memur ve hat bakımı gibi sürekli masrafların yaratacağı yükten kaçınmaktaydı. Şöyle ki Posta ve Telgraf Meclisinin 1386 sayılı kararı Seraskerliğin talep ettiği hatlarla ilgili Mühendis Kaleminden düzenlenen harita ile altı kıta keşif-nameden anlaşıldığı üzere adı geçen hatlara gerekli olan eşya pahasıyla diğer masraflar için 27439 Frank 10 santimle 255036 kuruş ahali tarafindan taahhüt olunsa bile maaşlar ve daimi masraflar için 1935 Frank ile 153580 kuruşa bütçede karşılık olmadığ için bu hatların ertelenmesi yönündedir. Bu kararın gerekçelerinden biri de bu hatlardan elde edilecek gelirin ödenecek maaş ve masrafların 1/3'ü derecesine bile ulaşamayacağı mahalleri başmüdürlüklerinden

\footnotetext{
${ }^{75}$ BOA, ŞD. 1790/27, 11 Mart 1895 (1312.N.14).

${ }^{76}$ BOA, ŞD. 1790/27, 11 Mart 1895 (1312.N.14).

${ }_{77}^{70}$ BOA, DH. MKT. (Dahiliye Nezareti Mektubi Kalemi) 1760/85, 13 Eylül 1890 (1308.M.28).

${ }^{78}$ Amasya'daki merkezlere telgraf açılması da en az Tokat-Erbaa-Niksar hattı gibi oldukça zor olmuş; söz konusu merkezlere hat çekilmesi uzun seneler almıştır. Bu konuda detaylı bilgi için bk. Edip Uzundal, Sultan II. Abdülhamid Dönemi’nde Amasya Sancă̆ı (Sosyal, Ekonomik, İdari ve Demografik Yapı), (Gaziosmanpaşa Üniversitesi Sosyal Bilimler Enstitüsü Yayımlanmamış Yüksek Lisans Tezi), Tokat 2017, s. 302-311.

${ }^{79}$ BOA, BEO. 252/18836, s. 3-1, 16 Ekim 1892 (1310.RA.24).

${ }^{80}$ BOA, BEO. 93/6956, 23 Ekim 1892 (1310.R.1).
} 
sorularak alınan cevaplardan ve vakanın araştırılmasından anlaşılmış olmasıdır (19 Zilhicce sene 1310/ 21 Haziran 1309/4 Temmuz 1893) ${ }^{81}$. Seraskerlik makamına 25 Temmuz (1)309/6 Ağustos 1893'te müsteşar tarafindan gönderilen yazı ile bu kararın 4. Ordu Müşirliğine iletilmesi belirtilmiştir ${ }^{82}$.

Seraskerliğin talebi üzerine yeni raporlar ve pusulalar hazırlanmıştır. Seraskerliğin açılmasını istediği yeni hatları gösteren bir haritada çizilmiştir (Bk. Harita 3). 23 Muharrem 1311/6 Ağustos 1893 numaralı dosyada yer alan belgeler Merzifon-Hacıköy, GümüşhaneKelkit-Şiran, Arapgir-Ağın, Niksar-Erbaa-Tokat arası hatlar için Posta ve Telgraf Nezareti Mühendis Kalemi tarafından hazırlanan keşif pusulalarından ibarettir. Niksar, Erbaa'da telgrafhane inşası gideri olmasa da diğerlerinde 10000 kuruş telgrafhane inşa masrafi bulunmaktadır. Bu pusulalara göre bu hatların mesafesi ve muhtemel direk sayıları aşağıdaki tabloda belirtilmiştir. $\mathrm{Bu}$ tablo incelendiğinde aynı anda telgraf hattı talebinde bulunan merkezler içerisinde en uzun hat Niksar-Erbaa-Tokat hattı olup hat için 1400 direğe ihtiyaç bulunmaktadır. Mesafe ve direk sayıları dikkate alındığında iki direk arası ortalama mesafenin 64,285 mt. olduğu görülmektedir. Diğer hatlarda bu mesafe 71,42 mt.’ye çıkmaktadır.

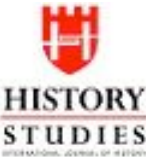

83

Volume 9

Issue 4

November 2017

\begin{tabular}{|c|c|c|c|c|}
\hline Hat Adı & $\begin{array}{l}\text { Mesafe } \\
\text { (kilometre) }\end{array}$ & $\begin{array}{l}\text { Mesafe } \\
\text { (metre) }\end{array}$ & $\begin{array}{l}\text { Kullanilacak } \\
\text { direk } \\
\text { (adet) }\end{array}$ & $\begin{array}{lr}\text { İki direk } & \text { arası } \\
\text { tahmini } & \text { mesafe } \\
\text { (metre) } & \end{array}$ \\
\hline $\begin{array}{l}\text { Niksar-Erbaa- } \\
\text { Tokat }\end{array}$ & 90 & 90000 & 1400 & 64,285 \\
\hline $\begin{array}{l}\text { Ladik-Havza- } \\
\text { Vezirköprü }\end{array}$ & 45 & 45000 & 630 & 71,42 \\
\hline Merzifon-Hacıköy & 20 & 20000 & 280 & 71,42 \\
\hline $\begin{array}{l}\text { Alacahan-Divriği } \\
\text { (+Alacahan- } \\
\text { Kangal yenileme) }\end{array}$ & 60 & 60000 & 840 & 71,42 \\
\hline Kelkit-Şiran & 40 & 40000 & 560 & 71,42 \\
\hline 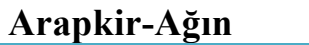 & 20 & 20000 & 280 & 71,42 \\
\hline
\end{tabular}

Kaynak: BOA, BE0, 252/18836, 8-1; 9-1; 10-1; 11-1.

\footnotetext{
${ }^{81}$ BOA, BEO, 252/18836, s. 4-1, 4 Temmuz 1893 (1310.Z.19/21 Haziran 1309). Posta ve Telgraf Nezareti Mektubi Kalemi 31 numaralı yazı Askeri açıdan haberleşmenin sürdürülmesi için ismi yazılı mahallere telgraf hattı ulaştırılması; Niksar hattının Tokat sancağına bağlanması hakkında sadarete ulaşan tezkerenin gereği olarak 143 numara ve 10 Teşrin-i Evvel sene 308 /22 Ekim 1892 tarihli Sadaretten gelen tezkeredir. Adı geçen mahalle hat bağlanması için gerekli eşya ve diğer masraflar ahali tarafından taahhüt verilecek olsa bile memur maaşları gibi daimi masraf olarak sarfi gereken meblağın bütçe içerisinde karşılığı olmadığı gibi Nezaret veznesi müsait olmadığından bunların da bazı benzerleri hakkındaki karar eklenerek şimdilik hatların birleştirilmesinden kaçınılması hususunda Telgraf ve Posta Nezareti İdare Meclisinden çıkan mazbata ve diğer ekleri içermektedir (15 Muharrem sene 311/29 Temmuz 1893).

${ }^{82}$ BOA, BEO, 252/18836, s. 1-1, 6 Ağustos 1893 (25 Temmuz 1309).
} 


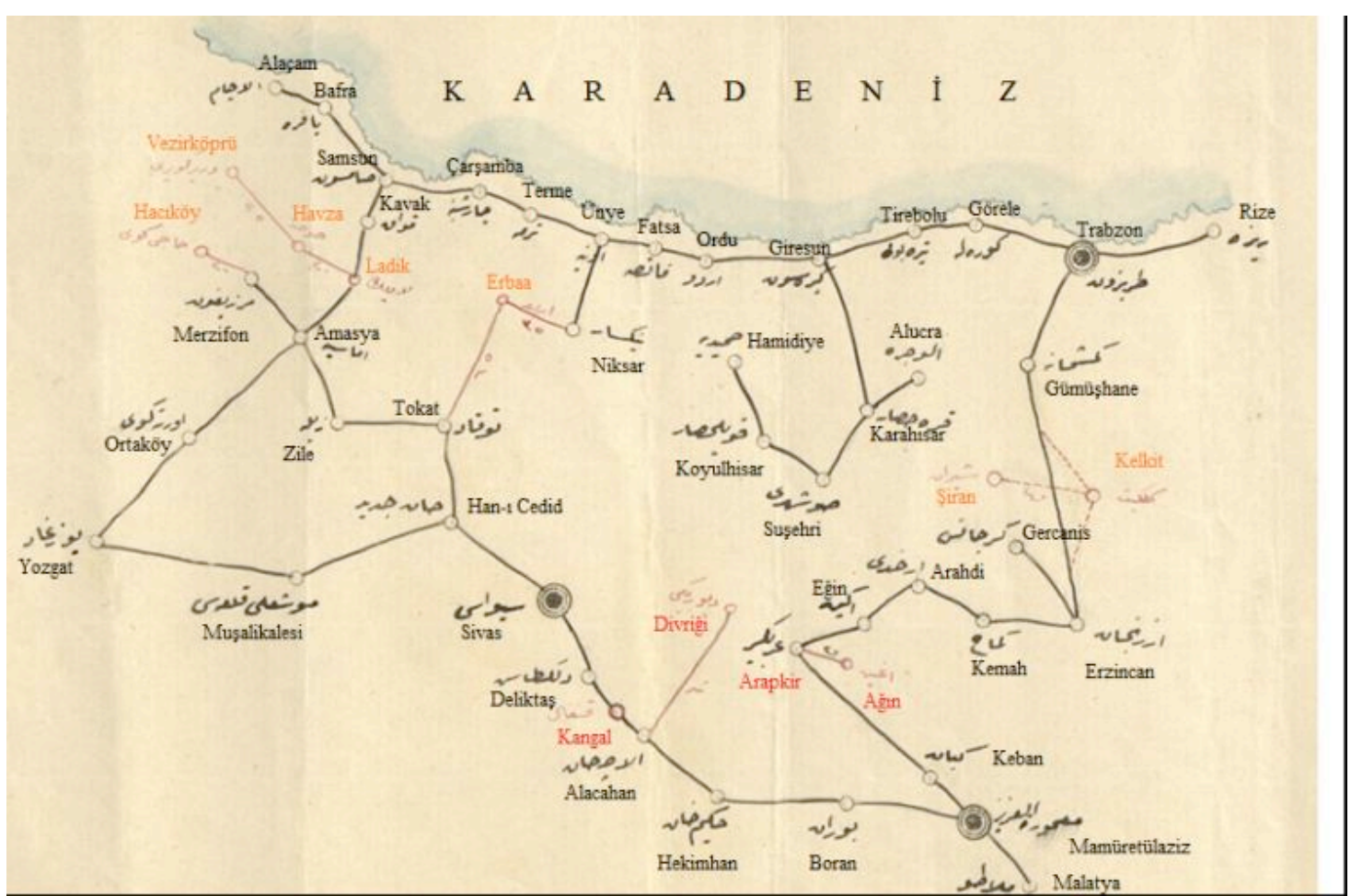

Harita 3. 1892'de Trabzon ve Sivas Vilayetlerinde Telgraf Bekleyen Merkezler

Posta ve Telgraf Nezareti Mühendis Kalemi 84 adetli keşif pusulası Niksar-Erbaa-Tokat hattı ve bu hattın masraflarına ilişkindir. Niksar'dan 35 km. uzakta Erbaa'ya ve Erbaa'dan 65 $\mathrm{km}$. mesafede bulunan Tokat'a kadar birleştirilmesi düşünülen ve inşâ edilecek hat için gerekli eşya vs.nin içinde yer aldığı bir keşif pusulasıdır (23 Teşrin-i Sâni sene 308/5 Aralık 1892). Bu pusulaya göre Masârif-i Te'sîsiye başlığında verilen hattın kuruluş masrafları içerisinde 4 ve 2 mm. kalınlıklarında demir teller, lehim, nişadır tuzu, bant kağıdı, Mors makinesi, laklanşe takımı, çavuş takımı, hamız, ince ve kalın lastikli teller bulunuyordu. Çeşitli ağırlık, uzunluk ve adette olan bu eşyaların maliyeti temin ücreti ve gümrük vergisiyle beraber 7639 Frank 25 santimi bulmaktaydi.

\section{Kuruluş Masrafi}

\begin{tabular}{lllll}
\hline Eşyanın Cinsi & Toplam miktar & Birim Ücreti & Frank & Santim \\
\hline $\mathbf{4}$ mm.lik demir tel & $10000 \mathrm{~kg}$. & 0,32 Frank & 3200 & 0 \\
$\mathbf{2}$ mm.lik demir tel & $20 \mathrm{~kg}$. & 0,40 Frank & 8 & 0 \\
Lehim & $30 \mathrm{~kg}$. & 3 Frank & 90 & 0 \\
Nişadır tuzu & $10 \mathrm{~kg}$. & 1 Frank & 10 & 0 \\
Band kağıdı & $20 \mathrm{~kg}$. & 1 Frank & 20 & 0 \\
Mükemmel Mors Makinesi & 4 aded & 380 Frank & 1520 & 0 \\
Küçük Model Osmanlı İzolatörü & 1500 aded & 1,15 Frank & 1720 & 0 \\
Laklanşe Takımı & 50 aded & 3 Frank & 150 & 0 \\
CCavuş Takımı & 4 aded & 65 Frank & 260 & 0 \\
Hamız & 5 şişe & 7 Frank & 35 & 0 \\
İnce lastikli tel & $30 \mathrm{mt}$. & 0,45 Frank & 13 & 50 \\
Kalın lastikli tel & $15 \mathrm{mt}$. & 0,85 Frank & 12 & 75 \\
Ara Toplam & & & 7044 & 25 \\
\hline
\end{tabular}


Murat HANILÇE

\begin{tabular}{lll}
\hline Temin ücreti $(\% \mathbf{0 , 5})$ & 35 & 0 \\
Gümrük resmi $(\% \mathbf{8})$ & 560 & 0 \\
Toplam & 7639 & 25 \\
\hline
\end{tabular}

Kaynak: BOA, BEO, 252/18836, 8-1.

$\mathrm{Bu}$ kuruluş masrafları içerisinde temin edilen eşyanın nakliyesi ve diğer masraflar da ayrı bir kalemde toplanmaktaydı. Pusulada belirtildiğine göre eşyalar İstanbul'dan Ünye'ye deniz, Ünye'den Niksar'a kara yoluyla nakledilecekti. Hat için gereken 1400 ahşap direğin her biri 30 kuruştan satın alınacak, dikilmesi için 10 kuruş harcanacaktı. Eşyanın inşaat mahallinde dağıtılması için de bir bütçe düşünülmüştü. Son olarak açılacak telgraf merkezinin mefruşatı için de bir bedel öngörülmüştü. Bütün bunların toplam1 62913 kuruş tutarındaydı.

Nakliye ve Diğer Masraf

HISTORY STUDIES

85

Volume 9

Issue 4

November 2017

\begin{tabular}{ll}
\hline İş Adı & Kuruş \\
\hline İstanbul'dan Ünye'ye kadar 12540 kilogram eşyanın deniz yoluyla nakliyesine & 1893 \\
Ünye'den Niksar'a kadar 12540 kilogram eşyanın kara yoluyla nakliyesine & 1800 \\
\hline Her biri 30 guruşdan 1400 adet ahşap direk satın alınmasına & 42000 \\
\hline Her biri 10 kuruştan 1400 adet ahşap direğin dikilmesine & 14000 \\
\hline Eşyanın inşaat mahallinde dağıtılmasına & 1500 \\
Merkezin teşrif masrafına & 1000 \\
Toplam & 62193 \\
\hline
\end{tabular}

Kaynak: BOA, BEO, 252/18836, 8-1.

Böyle bir telgraf hattı açılması durumunda bir sene içerisinde olağan bazı masraflar da ortaya çıkacaktı. Bunlar ilgili pusulada daimi masraflar başlığında verilmişti. Olağan masraflar olarak yenilenmesi gereken eşya, hattın tamiri, merkezin küçük giderleri ve merkezin basıl evrak ihtiyacı vardı. Bunların yıllık tutarı 455 Frank ve 7000 kuruş ederindeydi.

\section{Bir Senelik Olağan Masraflar}

\begin{tabular}{lll}
\hline İş Adı & Frank & Kuruş \\
\hline Yenilenmesi lazım gelen, Avrupa'dan celp olunacak eşya pahasına & 455 & 0 \\
\hline Hattın tamirine & 0 & 5600 \\
Merkezin küçük giderlerine & 0 & 1000 \\
Merkezin basılı evrakına & 0 & 400 \\
Toplam & 455 & 7000 \\
\hline
\end{tabular}

Kaynak: BOA, BEO, 252/18836, 8-1.

Daimi masraflar içerisinde bir memur, dört çavuş ve bir muvassıla ödenecek aylık maaş da belirtilmişti. Memur maaş1 500, çavuş maaşı 300 ve muvassıl maaşı 200 kuruş olarak yazılmıştı. Bu maaşların aylık toplamı 1900, yıllık toplamı ise 22800 kuruştu.

Maaşlar

\begin{tabular}{|ll}
\hline Maaş & Kuruş \\
\hline $\mathbf{1}$ memur maaşına & 500 \\
\hline $\mathbf{4}$ çavuş maaşına & 1200 \\
$\mathbf{1}$ muvassıl maaşına & 200 \\
Aylık maaş toplamı & 1900 \\
\hline Senelik maaş toplamı & 22800 \\
\hline
\end{tabular}

Kaynak: BOA, BEO, 252/18836, 8-1. 
1894'te Niksar-Erbaa-Tokat hattı için gerekli meblağın karşılanması için çabalar olmuştur. Hatta sadrazam bu konuda gerekli iznin verilmesini bildirmiştir. Umur-1 Dahiliye Nazırının imzasını taşıyan Bâbıali Daire-i Umur-1 Dâhiliye Mektûbî Kaleminden 64974 numara ve 2163 adetle çıkan tezkere sadarete gönderilmiştir. Hattın maaş ve daimi masrafı olan 450 Frank ile 22800 kuruşun bütçeden düzenlenmesi hakkında Telgraf ve Posta Nezaretinden alınan 28 Ağustos [1]310/9 Eylül 1894 tarih ve 152 numaralı tezkere ekiyle birlikte sunulup gereğinin yapılması için Sadaretten izin istenmiştir (18 Rebiü'l-evvel [1]312/19 Eylül 1894) ${ }^{83}$. Bu husus Telgraf ve Posta Nazırı imzasını taşıyan Telgraf ve Posta Nezareti Mektubi kaleminden çıkan adet 152 ve 9 Rebiü'l-evvel [1]312/10 Eylül 1894 tarihli tezkere ile Dahiliye Nezaretine iletilmiştir ${ }^{84}$. 29 Cemaziye'l-evvel 1312/28 Kasım 1894 tarihinde Dahiliye Nezaretine gönderilen tezkereyle de Tokat'tan Erbaa'ya kadar bağlanacak telgraf hattının daimi masrafları için Nezaretin izin vermesi istenmiştir. Tezkere, 19 Teşrin-i Sani [1]310/1 Aralık 1894'te ilgililerine ulaştırılmıştır ${ }^{85}$.

1895 senesine gelindiğinde bütçeden kaynaklı pürüzlerin büyük ölçüde ortadan kalktığı anlaşılmaktadır. Posta ve Telgraf Nezareti Meclisi Adet 287 tezkerede Sivas Vilayetinden gelen 153 numara ve 23 Haziran [1]309/5 Temmuz 1893 tarihli telgraf-namede Tokat'tan Erbaa'ya birleştirilmesi irade-i seniye gereği olan telgraf hattı için Avrupa'dan satın alınması ve celbi lâzım gelen telgraf eşyası bedeliyle kuruluş masrafları olan toplam 4400 Frank 60 santim ahali tarafindan yardım yoluyla verildiği ve direk bedeliyle dikilmesi masrafı ahaliye yüklendiği beyanıyla hattın hızla yapılması gereği bildirilmiştir. Bu şekilde cereyan eden haberleşme ve muameleye karşın söz konusu meblağın poliçesi gelerek tamamen vezneye teslim edildiği ve hattın yıllık tamir, güçlendirme, çeşitli masrafı ve matbu evrak bedeli olarak 450 Frank ile 7000 ve aylık 500 kuruşla bir memur ve 300'er kuruşla dört çavuş ve 200 kuruşla da bir müvezzi maaşı olarak 22800 kuruşun yıllık olmak üzere harcanması gerekli olup anılan daimi masraf ve maaşın [1]309/1892 senesi bütçesinde dâhil bulunduğu anlaşılmış olduğundan hattın açılması, maaş ve diğer masrafların bütçede düzenlenmesi ve izin verilmesi kararlaştırılmıştır (13 Safer [1]311/16 Ağustos 1895) ${ }^{86}$. Belgenin 1895 tarihli belgeler arasında bulunmasına rağmen 1892-93 yılına ait olması daha önceki girişimlerde bürokratik yavaşlığın hattı yavaşlattığı ve ertelediği sonucunu doğurmaktadır.

Erbaa'nın yılan hikâyesine dönen ve yıllar alan mutasarrıflık merkezi Tokat'a bir telgraf hattıyla bağlanma isteği bir dönem Sivas Valiliği yapan ve şehirde bayındırlık ve yol faaliyetleriyle öne çıkan Halil Rıfat Paşa'nın 1895'te sadrazamlık makamına getirilmesiyle cevap bulmuştur. Sadrazamın Padişah İkinci Abdülhamid'e gönderdiği 16 Receb 1313/2 Ocak 1896 tarihli tezkere bu durumu kanıtlamaktadır. Adı geçen tezkerede Erbaa ile Niksar arasında bilhassa askeri haberleşme için gerekli olan ve masrafı ahali tarafından verilmek üzere bir telgraf hattı bağlanmasının Seraskerlik tarafından talep edildiği belirtilmiştir. Hattın inşası için eşya pahasıyla diğer kuruluş masrafları olarak 2635 Frank 20 santimle 18870 kuruşun bir defalık ve hattın korunması için aylık 300'er kuruştan iki çavuş maaşı olarak 600 kuruşun aylık ve daimi olmak üzere harcanması lazım geldiği dile getirilmiştir. Diğer kalemlerin tamamlandığı vurgulanarak yalnız maaşın bütçeye ek olarak eklenmesi hususunun Telgraf ve Posta Nezaretine tebliği meselesi kalmıştır. Bu durumun çözülmesi için padişahın izni istenmiştir. Padişahın bu konudaki izni belgenin Serkatib Tahsin imzasını taşıan derkenarından anlaşıldığına göre 20 Receb 1313/6 Ocak 1896' da çıkmıştır. Hattın açılması için

\footnotetext{
${ }^{83}$ BOA, ŞD. 2639/44, 18 Ekim 1894 (1312.R.17).

${ }^{84}$ BOA, ŞD. 2639/44, 18 Ekim 1894 (1312.R.17).

${ }^{85}$ BOA, BEO, 524/39235, 28 Kasim 1894 (1312.CA.29).

${ }^{86}$ BOA, ŞD. 2639/44, 18 Ekim 1894 (1312.R.17).
} 
gerekenin yapılmasına dair bir der-kenarda belge içerisinde yer almıştır ${ }^{87}$. Böylece 1887 'de başlayan yoğun girişimler meyvesini vermiş; 1896 senesi itibarıyla Erbaa Osmanlı telgraf ağına dahil olmuştur. Erbaa Telgraf merkezinde yukarıdaki pusulalarda belirtilenin aksine yalnız bir memur tayin edildiği 1903 senesi itibarıyla anlaşılmaktadır. 1903'te Erbaa Telgraf Memuru olan Kamil Efendi 1907 senesinde hala bu görevdeydi (Bk. Ek-6).

1896 sonrası tamamlandığı düşünülen Erbaa Telgraf hattının Niksar'a uzatılıp uzatılmadığı hakkında belgeler ve haritalar tam olarak bilgi vermemektedir. Yalnız NiksarÜnye arasında tel kırıklığı meselesinde bu hattın yapılmaya başlandığına dair bir belge vardır (Bk. Niksar'a Telgrafın Gelişi). Bu belgede Niksar-Erbaa hattı için bölgede bulunan Müşir Şakir Paşa'nın Niksar-Tokat telgraf hattının kurulmasıyla ilgilendiği ve İstanbul'dan hat için gereken eşyaların gönderildiği bilgisine rastlanmaktadır. Bu durum adı geçen tarihte hattın Niksar'a bağlandı̆̆ını da göstermektedir.

\section{Sonuç ve Değerlendirme}

Sivas Vilayet merkezi, İngilizlerin Londra-Hindistan arasında kuracağı hat üzerinde yer almış ve 1859 senesi gibi erken bir tarihte Osmanlı telgraf hattına dâhil olmuştur. Sivas Vilayetine bağlı Tokat kazası şehirdeki bakır endüstrisi ve şehrin politik önemi dikkate alınarak 1868 senesinde Sivas'a ulaşan bir hata sahip olmuştur. 1870'te Amasya'ya bağlı Zile kazası sancak merkezi Amasya ile bir hatla bağlanmıştır. 1873'te Canik Mutasarrıflığına bağlı Niksar, Ünye üzerinden sancak merkezi Canik'le telgraf bağlantısına kavuşmuştur. Amasya livası kazalarından Erbaa'nın telgraf bağlantısı ise sürekli gözden kaçmış ya da göz ardı edilmiştir.

1880'de Tokat'ın mutasarrıflık haline getirilip Amasya livasına bağlı Erbaa ve Zile ile Canik livasına bağlı Niksar'ın Tokat sancağı idaresine girmesi bu kazaların Tokat Merkez kazasıyla doğrudan telgraf bağlantısı kurmasını zorunlu hale getirmiştir. Bu yönde ilk girişim

Tokat-Zile hattının kurulması olmuş ve söz konusu hat 1880 'de açılmıştır. Ne var ki Erbaa'da bir telgraf hattı kurulması uzun ve yorucu bir süreç sonunda gerçekleşmiştir.

Erbaa'ya bir telgraf merkezi açılması Niksar'la bir arada ele alınmıştır. Bütün projeler ve hesaplamalar bu duruma göre şekillendirilmiştir. Söz konusu hat için Tokat mutasarrıflığ 1 ve Erbaalı yerel idareciler, halk isteklerini merkeze iletmeye başlamıştır. Birçok yerde olduğu gibi halk telgrafhane binası inşası, direk temini ve dikilmesine talip olmuş ve bu masrafi üstlenmiştir. Hatta hat açılmadan Erbaa'da bir telgraf binası yapılmıştır. Erbaa tüccarı ellerindeki iç borçlanma kuponlarını bina için vermişlerdir. Tokat-Çilkoru arası Tokat; Çilkoru-Erbaa arası Erbaa ve Erbaa-Niksar arası için Niksar ahalisi bahsedilen direk masrafını üstlenmeye razı olmuştur. Niksar için bu hat Ünye-Samsun-Amasya-Yozgat ve Sivas'1 dolaşıp Tokat'a ulaşan ve epey bir mesafeyi kapsayan bir hat yerine daha kısa bir hat anlamına gelecekti. Zira 22 saat uzaklıktaki Niksar-Ünya hattında zaman zaman meydana gelen kablo kırıklıklarının tamiri gecikmekte ve iletişimde aksamalar meydana gelmekteydi. Öte yandan Niksar'dan çıkan bir telgrafin Tokat'a ulaşması için Ünye-Samsun-Amasya-Yozgat-Sivas'1 dolaşan bir hat üzerinden Tokat merkezine ulaşması iki merkezin iletişimini geciktirmekteydi. Erbaalılar ise ticari ve resmi açıdan en azından mutasarrıflık merkezi Tokat'la daha hızlı haberleşmek istemekteydi. Aslında sorun Erbaa'nın telgrafla küçülen dünyanın bir parçası olmak arzusuydu. Hat için 1887 'de yoğunlaşan girişimler ancak 1896'da sona ermiştir. Sürecin bu kadar uzaması bazı faktörlere dayanmaktadır: Bunlardan ilki Erbaa-Tokat hattının tek başına bir konu olmayıp Sivas ve Trabzon vilayetlerindeki bazı livalardaki ara hatlarla bir bütün olarak ele alınmasıdır. $\mathrm{Bu}$ durum hiç şüphesiz toplamda devlete büyük yük

${ }^{87}$ BOA, BEO. 727/54478, 9 Ocak 1896 (1313.B.23). 
getirmektedir. Buna bütün Osmanlı coğrafyasındaki telgraf istekleri eklendiğinde devletin bütçesinden çıkan rakamın daha büyük olacağı aşikardır. Haliyle devlet önceliği birinci derecede hatlara vermekte, Erbaa gibi iki ya da üçüncü derecede hatları geri plana atmaktadır. Devlet bu konuda vatandaşını üzmemekte, telgraf hattı için fizibilite çalışmalarını yapmakta ancak bütçe yetersizliğini gerekçe göstererek bu gibi hatların açılmasını sürekli ertelemektedir. Buna bir de devlet içerisindeki hiyerarşik yapı, Telgraf ve Posta Nezaretinin bağımsız bir yapıya sahip olmaması, Dahiliye Nezaretine bağlı hareket etmesi, belirli konularda Maliye Nezaretine danışılması zorunluluğu, Şura-yı Devletin konuyu görüşüp değerlendirmesi gibi bürokratik karmaşa işin uzamasının bir diğer önemli nedeni gibi durmaktadır. Devletin bu gibi hatlarda yavaşlığı biraz da buralara açılacak telgrafhanelerin gelirlerinin giderlerini karşılamayacağına olan inançtır.

Bu kadar geciken Erbaa-Tokat hattının 1896'da açılma kararına etki eden iki konu göze çarpmaktadır. Birincisi bu tarihte bir dönem Sivas Valiliği yapan Halil Rıfat Paşa'nın sadrazam olması ve konuyla yakından ilgilenmesidir. Bir ikinci konu olarak 4. Ordunun konuya yaklaşımıdır. Belgelerde açıkça belirtilmese de 1894-1899 arasında Tokat ve çevresinde Ermeni faaliyetlerinin çoğalması ve bu güvenlik meselesinin Erbaa'ya telgraf hattının kurulmasını hızlandırmış olabileceği ihtimalidir.

KAYNAKÇA

\section{Başbakanlık Osmanlı Arşivi}

Meclis-i Vala

Sadaret Mektubi Kalemi Mühimme Evrak1

İrade Dahiliye

Bab-1 Ali Evrak Odası

Dahiliye Nezareti Mektubi Kalemi

Vilayet Salnameleri

Trabzon 1286/1869; 1287/1870; 1296/1879.

Sivas $1287 / 1870 ; 1288 / 1871 ; 1289 / 1872 ; 1292 / 1875 ; 1293 / 1876 ; 1298 / 1880 ; 1300 / 1882$; $1301 / 1883 ; \quad 1302 / 1884 ; \quad 1304 ; \quad 1886 ; \quad 1306 / 1888 ; 1308 / 1890 ; \quad 1321 / 1903$; $1325 / 1907$.

Düstur, Tertip I, C.2.

\section{Araştırma Eserleri}

AÇIKEL, Ali, "Tokat Sancağının İdari Durumu ve Nüfus Yapısı (1880-1907)" Firat Üniversitesi Sosyal Bilimler Dergisi, C. 14, S. 2, Temmuz 2004, s. 331-359.

AÇIKEL, Ali-Mehmet Mercan, "Niksar Kazasının İdari Durumu ve Nüfus Yapısının Dini ve Etnik Açıdan Analizi (1880-1916)", Hacettepe Üniversitesi Edebiyat Fakültesi Dergisi, C. 19, S. 2, 2002, s. 235-257.

AHBAB, Yakub, “İletişimde Yeni Dönem: Üsküp'te Telgraf”, Yakın Dönem Türkiye Araştırmalart, C. 13, S. 25-26, 2014, s. 83-97.

AKBULUT, Uğur, "Suriye’ye İlk Telgraf Hatlarının Çekilmesi”, History Studies, C. 2, Ortadoğu Özel Sayısı, 2010, s. 1-11. 
AKTAŞ, Esat, XIX. Yüzyılın Son Çeyreğinde Tokat, (Gaziosmanpaşa Üniversitesi Sosyal Bilimler Enstitüsü Yayımlanmamış Yüksek Lisans Tezi), Tokat 2009.

ALTINDAL, Bekir, Zela'dan Zile’ye Tarihi Yolculuk, İstanbul 2011.

ALTUN, Esin, Doğu Anadolu Bölgesi'ne İlk Telgraf Hatlarının Çekilmesi, (Atatürk Üniversitesi Sosyal Bilimler Enstitüsü Yayımlanmamış Yüksek Lisans Tezi), Erzurum 2011.

Ana Britanica, “Telgraf”, C. 20, Ana Yayınc1lık, İstanbul 2000, s. 507-508.

ATA, Bahri, The Transfer of Telegraphy Technology to the Ottoman Empire in the XIXth Century, (Boğaziçi Üniversitesi Sosyal Bilimler Enstitüsü Yayımlanmamış Yüksek Lisans Tezi), İstanbul 1996.

BEZAZ, Yurda Güven, Haberleşme ve Tarihçesi, Türkiye Haber İş Sendikası Yayını, Ankara 2006.

Büyük Larousse, “Telgraf”, C. 22, Milliyet Yayını, İstanbul 1986, s. 11389-90.

CUINET, Vital, La Turquie D'Asie Géographque, Administrative, Statistique, Descriptive et Raisonnée de L'Asie-mineure, C. 1, Paris 1892.

ÇAKILCI, Diren, “Kıbrıs'a Telgrafın Gelişi: Lazkiye-Agios Theodoros Denizaltı Telgraf Hattı", Osmanlı Döneminde Klbris Uluslararası Sempozyumu (9-11 Ekim 2015) Bildiriler, Bağcılar Belediyesi Yayını, İstanbul 2016, s. 526-536.

ÇAKILCI, Diren, “Kıbrıs'ta Osmanlı Telgraf İşletmesi”, İstanbul Üniversitesi Edebiyat Fakültesi Tarih Dergisi, S. 62, 2015/2, s. 65-90.

ÇAKILCI, Diren, “Osmanlı Devleti’nde Uluslararası Telgraf İşbirliği: Sicilyateyn/İtalya Örneği”, Yakın Dönem Türkiye Araştırmaları, C. 13, S. 25-26, 2014, s. 51-81.

ÇAKILCI, Diren, “Osmanl1-Avrupa Telgraf Hatlarında Sırbistan Emareti'nin Rolü”, OTAM, S. 34, Güz 2013, s. 59-81.

ÇAKILCI, Diren, Rumeli Telgraf Hatları (1854-1876), (Akdeniz Üniversitesi Sosyal Bilimler Enstitüsü Yayımlanmamış Yüksek Lisans Tezi), Antalya 2015.

DAVISON, Roderic H., "Osmanlı İmparatorluğu'na Elektrikli Telgrafın Girişi”" Çev: Durdu Mehmet Burak, OTAM (Ankara Üniversitesi Osmanlı Tarihi Araştırma ve Uygulama Merkezi Dergisi), S. 14, Ankara 2003, s. 347-386.

DAVISON, Roderic H., "The Advent of the Electric Telegraph in the Ottoman Empire", Essays in Ottoman and Turkish History, 1774-1923, University of Texas Press, Texas 1990, s. 133-165.

DEMİR, Tanju, Türkiye'de Posta Telgraf ve Telefon Teşkilatının Tarihsel Gelişimi (18401920), PTT Yayınları, Ankara 2006.

DEMIR, Tanju, Türkiye'de Posta ve Telgraf ve Telefon Örgütünün Tarihsel Gelişimi 1840-1920, (Dokuz Eylül Üniversitesi Atatürk İlkeleri ve İnkılap Tarihi Enstitüsü Doktora Tezi), İzmir 2001.

ERÇİN, Emine Mehveş, 19. Yüzyılda Erbaa Kazası'nın Sosyo-Ekonomik Yapısı, (İstanbul Üniversitesi Sosyal Bilimler Enstitüsü Yayımlanmamış Yüksek Lisans Tezi, İstanbul 2005. 
ERSOY HACISALIHOĞLU, Neriman, "Kırım Savaşında Haberleşme: Varna Telgraf Hattı Şebekesi", Savaştan Barlşa: 150. Yıldönümünde Kırım Savaşı ve Paris Antlaşması (1853-1856) Bildiriler, İstanbul Üniversitesi Tarih Araştırma Merkezi Yayın1, İstanbul 2007, s. 119-130.

GÖKOĞLU, A. Baha, Batı ve Doğu'da Telgraf̧̧ılık Nasıl Doğdu?, İstanbul 1935.

HAMLEY, Cyrus, Among the Turks, New York 1876.

KAÇAR, Mustafa, "Osmanlı Telgraf İşletmesi”, Çă̆ını Yakalayan Osmanlı, Ed. Ekmeleddin İhsanoğlu, IRCICA Yayını, İstanbul 1995, s. 45-120.

KAÇAR, Mustafa, Osmanlı Telgraf İşletmesi (1854-1871), (İstanbul Üniversitesi Sosyal Bilimler Enstitüsü Yayımlanmamış Yüksek Lisans Tezi), İstanbul 1984.

KESKİN, Özkan-Ali Sönmez, “Telgraf’1n Osmanlı İmparatorluğu'nda Yayılması: Çanakkale Telgraf Hattı Örneği”, OTAM, S. 25, Bahar 2009, s. 67-81.

KESKİN, Şekip, Türk Posta Tarihi, Ulusal Matbaa, Ankara 1942.

KIVRIM, İsmail, Taşova-Erbaa Yerleşme-Nüfus Ekonomi (15-16. Yüzyıl), Kitabevi Yayın1, İstanbul 2014.

KUZUCU, Kemalettin, "Osmanlı Modernleşme Sürecinde İki Sivas Valisinin Raporlarının Karşılaştırılması ve Vilayetin Kentsel Dönüşümüne Etkileri”, .Osmanlılar Döneminde Sivas Sempozyumu Bildirileri (21-25 Mayls 2007), C. 1, Sivas Valiliği İl Kültür ve Turizm Müdürlüğü Yayını, Sivas 2007, s. 335-352.

MERCAN, Mehmet, "Giresun Telgraf İdaresi ve Telgrafhane Binas1 (1869-1904)", Uluslararası Giresun ve Doğu Karadeniz Sosyal Bilimler Sempozyumu (09 -11 Ekim 2008) Bildiriler, C. 1, Ankara 2009, s. 354-366.

MERCAN, Mehmet, "Sivas Vilayeti'nin Teşkili ve İdari Yapısı (1867-1920)", Osmanlılar Döneminde Sivas Sempozyumu Bildirileri (21-25 Mayls 2007), C. 1, Sivas Valiliği İl Kültür ve Turizm Müdürlüğü Yayını, Sivas 2007, s. 549-558.

MERCAN, Mehmet, "Tokat'1n Mutasarrıflık Oluşuna Dair Bir Belge", Tokat Kültür Araştırma Dergisi, S. 17, Aralık 2002, s. 5-13.

OKAN, Ayşegül, The Ottoman Postal and Telegraph Services in the Last Quarter of the Nineteenth Century, (Boğaziçi Üniversitesi Atatürk İlkeleri ve İnkılap Tarihi Enstitüsü Yayımlanmamış Yüksek Lisans Tezi), İstanbul 2003.

OLGUN, Said, "Posta ve Telgraf Mektebi Talimatnamesi", Yakın Dönem Türkiye Araştırmalarl, C. 13, S. 25-26, 2014, 149-181.

ÖZYÜREK, Yavuz, 16146 Numaralı Temettüat Defterine Göre Erbaa Kazası'na Bağlı Karayaka Nahiyesi'nin Sosyo-Ekonomik Yapısı, (Çankırı Karatekin Üniversitesi Sosyal Bilimler Enstitüsü Yayımlanmamış Yüksek Lisans Tezi), Çankırı 2012.

PTT Genel Müdürlüğü, Geçmişten Günümüze Posta, PTT Genel Müdürlüğü Yayını, Ankara 2007.

SERBESTOĞLU, İbrahim, Bir Taşra Şehrinde Tanzimat ve Modernleşme Canik Sancağ 1863-1865, Mengüceli Yayınları, Malatya 2015. 
SERBESTOĞLU, İbrahim-Abidin Temizer, “Amasya’ya Telgraf Hatlarının Çekilmesi”, Uluslararası Akdeniz Medeniyetleri Sempozyumu (8-10 Kasım 2016, Girne) Bildiri Kitabı, Gece Kitaplığı, Ankara 2017, s. 83-90.

ŞAHİN, Mahmut Hazım, Türkiye'de Yeri Değiştirilen Şehirlere Bir Örnek: Erbaa/Tokat, (Ondokuzmayıs Üniversitesi Sosyal Bilimler Enstitüsü Yayımlanmamış Yüksek Lisans Tezi), Samsun 2012.

Şemseddin Sami, Kâmusü'l-Âlam, C. 4, İstanbul 1311/1884.

TANRIKUT, Asaf, Türkiye'de Posta ve Telgraf ve Telefon Tarihi Teşkilatı ve Mevzuatı, Efem Matbaac1lı, Ankara 1984.

TOKMAK, Esin, Prizren'deki 19. Yüzyıl Osmanlı Dönemi Kamu Yapılarının İncelenmesi ve Prizren Eski Posta ve Telgraf Binası Iç̧in Koruma Önerisi, (Mimar Sinan Güzel Sanatlar Üniversitesi Fen Bilimleri Enstitüsü Yayımlanmamış Yüksek Lisans Tezi), İstanbul 2012.

TOPTAŞ, Seyfi, Ittihat ve Terakki Cemiyeti ve Osmanlı Posta ve Telgraf Teşkilatı, (Gazi Üniversitesi Sosyal Bilimler Enstitüsü Yayımlanmamış Yüksek Lisans Tezi), Ankara 2004.

TURAL, Erkan, “Osmanlı Posta Bürokrasisi 1908-1914”, Ankara Üniversitesi Tarih Araştırmaları Dergisi, C. 28, S. 46, 2009, s. 205-230.

UZUNDAL, Edip, Sultan II. Abdülhamid Dönemi'nde Amasya Sancă̆ (Sosyal, Ekonomik, Idari ve Demografik Yapı), (Gaziosmanpaşa Üniversitesi Sosyal Bilimler Enstitüsü Yayımlanmamış Yüksek Lisans Tezi), Tokat 2017.

Volume 9

WOODS, Robert O., "Makine Tarihi: Dünyay1 Küçülten Bir Telgraf Hattı-A Cable to Shrink the Earth", çev. Yeliz Demir, Mühendis ve Makina, C. 52, S. 615 (Nisan 2011), s. 41-46.

YAZICI, Nesimi, “Osmanlı Telgraf Fabrikası”, Türk Dünyası Araştırmaları Dergisi, S. 22, Şubat 1983, s. 69-81.

YAZICI, Nesimi, "Osmanlı Telgrafında Dil Konusu", Ankara Üniversitesi İlahiyat Fakültesi Dergisi, S. 26, 1983, s. 751-764.

YAZICI, Nesimi, “Tanzimatta Haberleşme ve Kara Taşımacılığı”, OTAM, S. 3, 1992, s. 333-375.

YAZICI, Nesimi, "Telgrafçılık Tarihine Bir Bakış ve Osmanlı Telgrafçılığının Başlaması (Türkiye'de İlk Telgrafı Abdülmecit Çekti)", Yıllarboyu Tarih, S. 7, Temmuz 1981, s. 23-26.

YAZICI, Nesimi, Osmanlı Devleti'nde Posta Teşkilatı (Tanzimat Devri), (Ankara Üniversitesi İlahiyat Fakültesi Yayımlanmamış Doktora Tezi), Ankara 1981.

YÜKSEL, Ahmet, "Suçluluk ve Suçsuzluk Arasında Osmanlı Telgraf Memurları", Uluslararası Sosyal Araştırmalar Dergisi, C. 7, S. 33, 2014, s. 373-389. 


\section{Ek 1- Sivas Vilayeti Telgraf ve Posta İdaresi (1870-1876)}

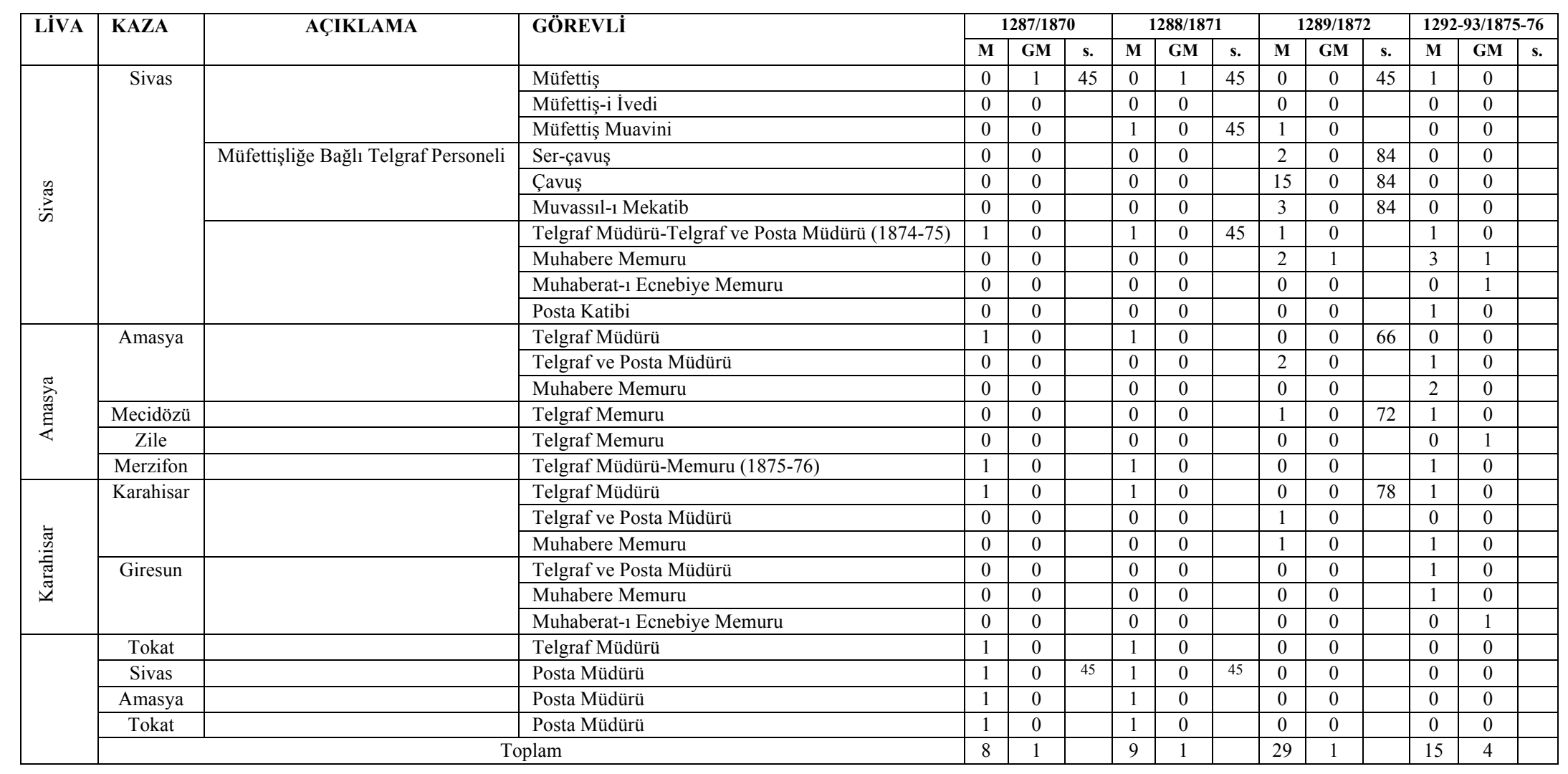




\section{Ek 2-Sivas Vilayeti Telgraf ve Posta İdaresi (1880-1890)}

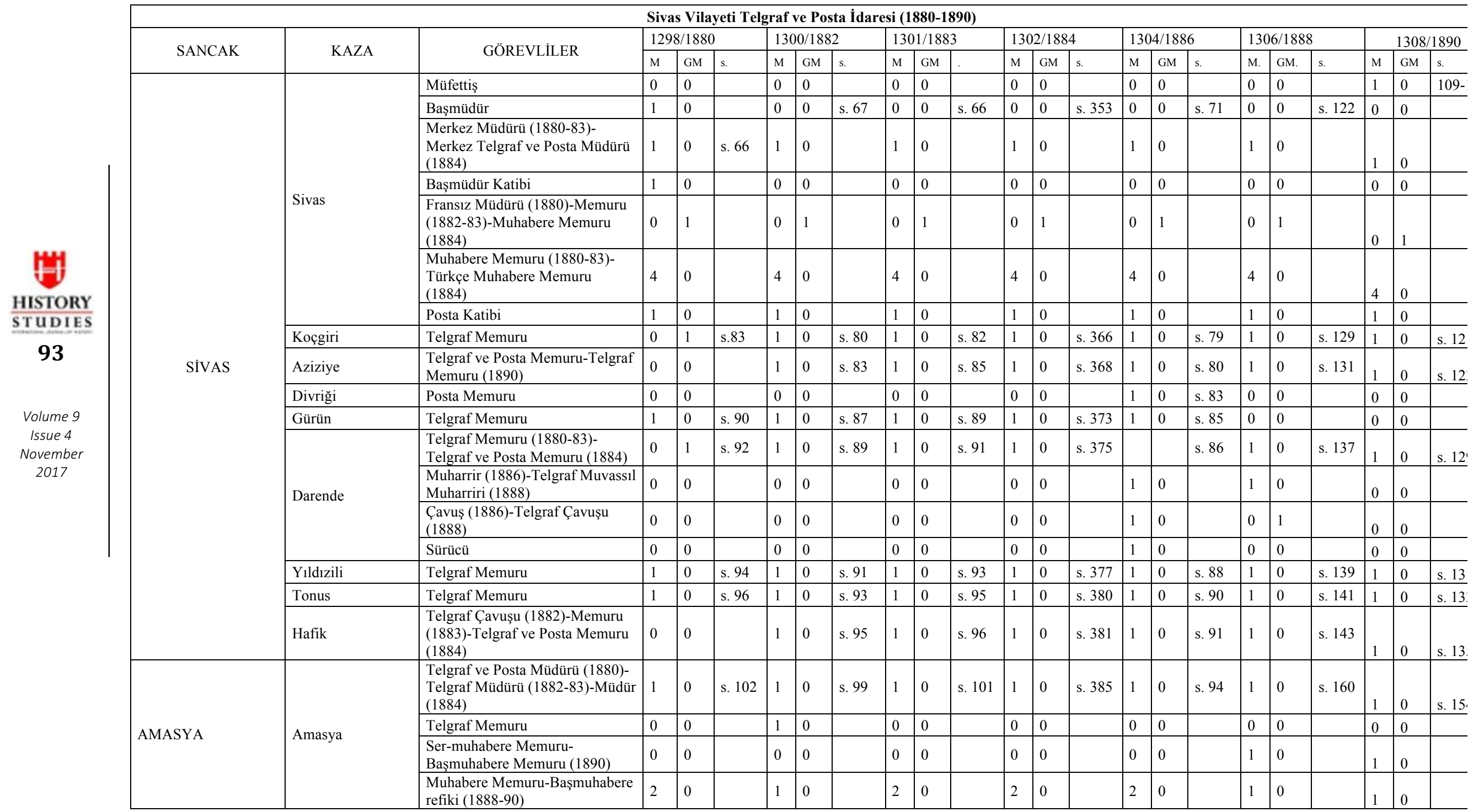




\begin{tabular}{|c|c|c|c|c|c|c|c|c|c|c|c|c|c|c|c|c|c|c|c|c|c|c|c|}
\hline & Merzifon & $\begin{array}{l}\text { Telgraf memuru(1880-86, 90)- } \\
\text { Telgraf ve Posta Memuru (1888) }\end{array}$ & 1 & 0 & s.104 & 1 & 0 & s. 103 & 1 & 0 & s. 106 & 1 & 0 & s. 391 & 1 & 0 & s. 99 & 1 & 0 & s. 164 & 1 & 0 & .158 \\
\hline & Maden-i Sim & $\begin{array}{l}\text { Posta Memuru (1888)-Telgraf } \\
\text { Memuru (1890) }\end{array}$ & 0 & 0 & & 0 & 0 & & 0 & 0 & & 0 & 0 & & 0 & 0 & & 1 & 0 & s. 167 & 1 & 0 & s. 16 \\
\hline & Mecidözü & $\begin{array}{l}\text { Telgraf Memuru (1880-83, 86, } \\
\text { 88))-Telgraf ve Posta Memuru } \\
\text { (1884) }\end{array}$ & 1 & 0 & s.118 & 1 & 0 & s. 113 & 0 & 1 & s. 117 & 1 & 0 & s. 403 & 1 & 0 & s. 110 & 1 & 0 & s. 177 & 1 & 0 & s. 17 \\
\hline & Havza & $\begin{array}{l}\text { Posta Memuru (1888)-Telgraf } \\
\text { Memuru (1890) }\end{array}$ & 0 & 0 & & 0 & 0 & & 0 & 0 & & 0 & 0 & & 0 & 0 & & 1 & 0 & s. 179 & 1 & 0 & s. 17 . \\
\hline \multirow{10}{*}{ TOKAT } & \multirow{6}{*}{ Tokat } & Telgraf ve Posta Müdürü & 1 & 0 & s. 124 & 1 & 0 & s. 120 & 1 & 0 & s. 124 & 1 & 0 & s. 412 & 1 & 0 & s. 117 & 1 & 0 & s. 147 & 1 & 0 & s. 14! \\
\hline & & Başmuhabere Memuru & 0 & 0 & & 0 & 0 & & 0 & 0 & & 0 & 0 & & 0 & 0 & & 1 & 0 & & 1 & 0 & \\
\hline & & $\begin{array}{l}\text { Muhabere Memuru-Başmuhabere } \\
\text { refiki (1888-90) }\end{array}$ & 1 & 0 & & 1 & 0 & & 1 & 0 & & 1 & 0 & & 2 & 0 & & 1 & 0 & & 2 & 0 & \\
\hline & & Muvassil & 1 & 0 & & 2 & 0 & & 2 & 0 & & 2 & 0 & & 2 & 0 & & 0 & 0 & & 0 & 0 & \\
\hline & & Hat Çavuşu & 1 & 0 & & 2 & 0 & & 2 & 0 & & 2 & 0 & & 2 & 0 & & 0 & 0 & & 0 & 0 & \\
\hline & & Şakird & 1 & 0 & & 1 & 0 & & 1 & 0 & & 1 & 0 & & 1 & 0 & & 0 & 0 & & 0 & 0 & \\
\hline & \multirow{3}{*}{ Zile } & Telgraf Memuru & 1 & 0 & s. 126 & 1 & 0 & s. 126 & 1 & 0 & & 1 & 0 & s. 417 & 1 & 0 & s. 121 & 1 & 0 & s. 153 & 1 & 0 & s. 14 \\
\hline & & Çavuş & 2 & 0 & & 2 & 0 & & 0 & 0 & & 0 & 0 & & 0 & 0 & s. 125 & 0 & 0 & & 0 & 0 & \\
\hline & & Muvassıl & 1 & 0 & & 1 & 0 & & 0 & 0 & & 0 & 0 & & 0 & 0 & & 0 & 0 & & 0 & 0 & \\
\hline & \begin{tabular}{|l|} 
Niksar \\
\end{tabular} & \begin{tabular}{|l|} 
Telgraf memuru \\
\end{tabular} & 1 & 0 & s.130 & 1 & 0 & s. 130 & 1 & 0 & & 1 & 0 & s. 422 & 1 & 0 & & 1 & 0 & s. 155 & 1 & 0 & s. 14: \\
\hline \multirow{7}{*}{$\begin{array}{l}\text { KARAHİSAR-I } \\
\text { ŞARKİ }\end{array}$} & \multirow{4}{*}{ Karahisar-1 Şarki } & Telgraf ve Posta Müdürü & 1 & 0 & s. 133 & 1 & 0 & s. 133 & 1 & 0 & s. 138 & 1 & 0 & s. 426 & 1 & 0 & s. 128 & 1 & 0 & s. 182 & 1 & 0 & s. 17: \\
\hline & & $\begin{array}{l}\text { Ser-muhabere Memuru (1888)- } \\
\text { Başmuhabere Memuru (1890) }\end{array}$ & 0 & 0 & & 0 & 0 & & 0 & 0 & & 0 & 0 & & 0 & 0 & & 1 & 0 & & 1 & 0 & \\
\hline & & Muhabere memuru & 1 & 0 & & 1 & 0 & & 1 & 0 & & 1 & 0 & & 1 & 0 & & 0 & 0 & & 0 & 0 & \\
\hline & & Şakird & 0 & 0 & & 0 & 0 & & 0 & 0 & & 1 & 0 & & 0 & 0 & & 0 & 0 & & 0 & 0 & \\
\hline & Suşehri & Telgraf Memuru & 0 & 0 & & 0 & 0 & & 0 & 0 & & 0 & 0 & & 0 & 0 & & 1 & 0 & s. 185 & 1 & 0 & s. 18 \\
\hline & Hamidiye & \begin{tabular}{|l} 
Telgraf Memuru \\
\end{tabular} & 0 & 0 & & 0 & 0 & & 0 & 0 & & 0 & 0 & & 0 & 0 & & 1 & 0 & \begin{tabular}{|l|l} 
s. 188 \\
\end{tabular} & 1 & 0 & s. 18 . \\
\hline & Koyulhisar & Telgraf Memuru & 0 & 0 & & 0 & 0 & & 0 & 0 & & 0 & 0 & & 0 & 0 & & 1 & 0 & s. 190 & 1 & 0 & s. 18 \\
\hline \multicolumn{3}{|c|}{ Toplam } & 28 & 3 & & 32 & 1 & & 28 & 2 & & 30 & 1 & & 33 & 1 & & 30 & 2 & & 31 & 1 & \\
\hline
\end{tabular}




\section{Ek 3-Sivas Vilayeti Telgraf ve Posta İdaresi (1903-1907)}

\begin{tabular}{|c|c|c|c|c|c|c|c|}
\hline \multirow{2}{*}{ SANCAK } & \multirow{2}{*}{ KAZA } & \multirow{2}{*}{ BİRIM } & \multirow{2}{*}{ GÖREVLİ } & \multicolumn{2}{|c|}{$1321 / 1903$} & \multicolumn{2}{|c|}{$1325 / 1907$} \\
\hline & & & & $\mathrm{M}$ & Sayfa & $\mathrm{M}$ & \\
\hline \multirow{30}{*}{ SIVAS } & \multirow{16}{*}{ SIVAS MERKEZ } & \multirow{3}{*}{ Telgraf ve Posta Dairesi } & Başmüdür & 1 & s. 64 & 1 & s. 67 \\
\hline & & & Müfettiş & 1 & & 0 & \\
\hline & & & Müfettiş Muavini & 1 & & 2 & \\
\hline & & \multirow{4}{*}{ Başmüdüriyet Kalemi } & $\begin{array}{l}\text { Tahrirat Katibi (1903)-Başkatip } \\
\text { (1907) }\end{array}$ & 1 & & 1 & \\
\hline & & & Sandık Emini & 1 & & 1 & \\
\hline & & & Muhasebe Katibi & 1 & & 1 & \\
\hline & & & Mukayyid & 0 & & 1 & \\
\hline & & \multirow{5}{*}{ Merkez Müdüriyeti } & $\begin{array}{l}\text { Telgraf Merkez Müdürü (1903)- } \\
\text { Posta ve Telgraf Müdürü (1907) }\end{array}$ & 1 & & 1 & \\
\hline & & & \begin{tabular}{|l|} 
Lisan-1 Ecnebi Şef[id]i \\
\end{tabular} & 1 & & 1 & \\
\hline & & & \begin{tabular}{|l|} 
Ser-memur \\
\end{tabular} & 1 & & 0 & \\
\hline & & & Muhabere Memuru & 9 & & 1 & \\
\hline & & & $\begin{array}{l}\text { Konak-1 Ali-i Vilayetpenahi } \\
\text { Memuru }\end{array}$ & 1 & & 0 & \\
\hline & & \multirow{4}{*}{$\begin{array}{l}\text { Posta Kism1 (1903)- } \\
\text { Kalemi (1907) }\end{array}$} & Posta Müdürü & 1 & & 1 & \\
\hline & & & \begin{tabular}{|l} 
Posta Müdürü Muavini \\
\end{tabular} & 1 & & 0 & \\
\hline & & & \begin{tabular}{|l|} 
Posta Memuru \\
\end{tabular} & 0 & & 1 & \\
\hline & & & Posta Katibi & 1 & & 1 & \\
\hline & Koçgiri & & $\begin{array}{l}\text { Telgraf ve Posta Müdürü (1903)- } \\
\text { Memuru (1907) }\end{array}$ & 1 & s. 93 & 1 & s. 115 \\
\hline & Aziziye & & $\begin{array}{l}\text { Telgraf ve Posta Memuru (1903)- } \\
\text { Müdürü (1907) }\end{array}$ & 1 & s. 95 & 1 & s. 106 \\
\hline & \multirow[t]{2}{*}{ Divriği } & & $\begin{array}{l}\text { Posta ve Telgraf Memuru (1903)- } \\
\text { Müdürü (1907) }\end{array}$ & 1 & s. 97 & 1 & s. 98 \\
\hline & & & Muhabere Memuru & 1 & & 1 & \\
\hline & Tonus & & Telgraf ve Posta Müdürü & 1 & s. 99 & 0 & \\
\hline & Yenihan & & Telgraf ve Posta Memuru & 1 & s. 101 & 1 & s. 102 \\
\hline & Bünyad-1 Hamid & & Telgraf ve Posta Müdürü & 0 & & 1 & s. 104 \\
\hline & Hafik & & Telgraf ve Posta Memuru & 1 & s. 105 & 1 & s. 108 \\
\hline & \multirow[b]{2}{*}{ Gürün } & & Posta ve Telgraf Müdürü & 0 & & 1 & s. 111 \\
\hline & & & $\begin{array}{l}\text { Telgraf ve Posta Memuru (1903)- } \\
\text { Muhabere Memuru (1907) }\end{array}$ & 1 & s. 107 & 1 & \\
\hline & \multirow{3}{*}{ Darende } & & Telgraf Müdürü & 0 & & 1 & s. 113 \\
\hline & & & Telgraf Memuru & 1 & s. 109 & 0 & \\
\hline & & & Telgraf Muvassil-1 Muharrerat & 1 & & 1 & \\
\hline & Kangal & & Telgraf ve Posta Memuru & 0 & & 1 & s. 118 \\
\hline \multirow{5}{*}{ AMASYA } & \multirow{5}{*}{ AMASYA MERKEZ } & \multirow{5}{*}{ Telgraf ve Postahane } & Müdür & 1 & s. 116 & 1 & s. 124 \\
\hline & & & Ser-muhabere Memuru & 1 & & 1 & \\
\hline & & & Muharebe Memuru & 4 & & 4 & \\
\hline & & & Muvassıl-1 Muharrerat & 2 & & 2 & \\
\hline & & & Zile Ciheti Hat Çavuşu & 1 & & 1 & \\
\hline
\end{tabular}




\begin{tabular}{|c|c|c|c|c|c|c|c|}
\hline & \multirow{6}{*}{ Merzifon } & \multirow{6}{*}{ Posta ve Telgraf Dairesi } & \multirow{3}{*}{\begin{tabular}{|l} 
Yozgad Ciheti Hat Çavuşu \\
Ladik Ciheti Hat Çavuşu \\
Müdür
\end{tabular}} & \multirow{2}{*}{$\frac{1}{1}$} & ${ }^{2}$ & \\
\hline & & & & & & \multicolumn{2}{|l|}{$\frac{1}{1}$} \\
\hline & & & & 1 & s. 119 & 1 & s. 128 \\
\hline & & & Muhabere Memuru & 1 & & 1 & \\
\hline & & & Telgraf Çavuşu & 1 & & 1 & \\
\hline & & & Muvassıl-1 Muharrerat & 1 & & 1 & \\
\hline & \multirow{2}{*}{ Köprü } & & Telgraf ve Posta Müdürü & 1 & s. 122 & 1 & s. 131 \\
\hline & & & Muhabere Memuru & 1 & & 1 & \\
\hline & Mecidözü & & Telgraf Memuru & 1 & s. 124 & 1 & s. 133 \\
\hline & Ladik & & Telgraf Memuru & 1 & s. 127 & 1 & .136 \\
\hline & \multirow{3}{*}{ Gümüşhacıköyü } & & Telgraf ve Posta Memuru & 1 & s. 130 & 1 & s. 139 \\
\hline & & & Muhabere Memuru & 1 & & 0 & \\
\hline & & & Muvassıl-1 Muharrerat & 1 & & 1 & \\
\hline & \multirow{2}{*}{ Havza } & & Telgraf ve Posta Memuru & 1 & s. 132 & 1 & s. 141 \\
\hline & & & Telgraf ve Muhabere Memuru & 1 & & 0 & \\
\hline \multirow{8}{*}{ TOKAT } & \multirow{2}{*}{ TOKAT MERKEZ } & \multirow{2}{*}{ Telgraf ve Posta İdaresi } & Müdür & 1 & s. 138 & 1 & s. 146 \\
\hline & & & Muhabere Memuru & 3 & & 3 & \\
\hline & Niksar & & $\begin{array}{l}\text { Telgraf ve Posta Memuru (1903)- } \\
\text { Müdürü (1907) }\end{array}$ & 1 & s. 142 & 1 & s. 151 \\
\hline & \multirow{4}{*}{ Zile } & & $\begin{array}{l}\text { Telgraf ve Posta Memuru (1903)- } \\
\text { Müdürü (1907) } \\
\end{array}$ & 1 & s. 145 & 1 & s. 154 \\
\hline & & & Muhabere Memuru & 1 & & 1 & \\
\hline & & & Muvassıl-1 Muharrerat & 0 & & 1 & \\
\hline & & & Hat Çavuşu & 0 & & 2 & \\
\hline & Erbaa & & Telgraf ve Posta Memuru & 1 & s. 146 & 1 & s. 158 \\
\hline \multirow{9}{*}{$\begin{array}{l}\text { KARAHISAR- } \\
\text { I ŞARKİ }\end{array}$} & \multirow{4}{*}{$\begin{array}{l}\text { KARAHISAR-I } \\
\text { ŞARKİ MERKEZ }\end{array}$} & \multirow{4}{*}{ Telgraf ve Posta İdaresi } & Müdür & 1 & s. 152 & Boș & s. 164 \\
\hline & & & Muhabere Memuru & 3 & & 3 & \\
\hline & & & Muvassıl-1 Muharrerat & 1 & & 1 & \\
\hline & & & \begin{tabular}{|l|} 
Telgraf Çavuşu \\
\end{tabular} & 2 & & 2 & \\
\hline & Hamidiye & & Telgraf ve Posta Müdürü & 1 & s. 154 & 1 & s. 166 \\
\hline & \multirow[t]{2}{*}{ Koyulhisar } & & $\begin{array}{l}\text { Telgraf Memuru Vekili (1903)- } \\
\text { Memuru (1907) }\end{array}$ & 1 & s. 158 & 1 & s. 170 \\
\hline & & & Muvassil-1 Muharrerat & 1 & & 0 & \\
\hline & Alucra & & \begin{tabular}{|l|} 
Telgraf Memuru \\
\end{tabular} & 0 & & 1 & s. 167 \\
\hline & Suşehri & & Telgraf Memuru & 0 & & 1 & s. 168 \\
\hline \multicolumn{4}{|c|}{ Toplam } & 74 & & 68 & \\
\hline
\end{tabular}

\section{Ek-4 Sivas Vilayeti Telgraf Tarifesi}

Telgraf Ücreti Tarifesi (1289/1872) (s. 84)

Sivas'tan vilayet içerisinde yer alan merkezlere 20 kelimesi 10 kuruştur. \begin{tabular}{|l|l|l}
\hline Sivas Vilayetinden Anadolu & Kurus & Sivas vilâyetinden Rumeli \\
\hline & 15 & Us
\end{tabular} 


\begin{tabular}{|l|l|l|l|l|} 
Ankara Vilayetine & 15 & Edirne Vilayetine & 40 & \\
\hline Aydın Vilayetine & 40 & İsod[u]ra Vilayetine & 60 & \\
\hline Bağdad Vilayetine & 30 & Bosna Vilayetine & 60 & \\
\hline Cezâyir-i Bahr-i Sefid Vilayetine & 30 & Selanik Vilayetine & 50 & \\
\hline Halep Vilayetine & 15 & Tuna Vilayetine & 50 & \\
\hline Hüdâvendigâr Vilayetine & 30 & Yanya Vilayetine & 60 & \\
\hline Diyarbekir Vilayetine & 15 & & & \\
\hline Suriye Vilayetine & 30 & & & \\
\hline Trabzon Vilayetine & 15 & & & \\
\hline Kastamonu Vilayetine & 15 & & & \\
\hline Konya Vilayetine & 15 & & & \\
\hline
\end{tabular}

\section{Ek-5 Sivas Vilayet Posta Dağıtımı}

HISTORY STUDIES

97

Volume 9 Issue 4

November

2017

\begin{tabular}{|c|c|c|}
\hline \multicolumn{3}{|c|}{ SIVAS VILAYETİ İÇINDE POSTA DAĞITIMI (1289/1872) (s. 85) } \\
\hline \multicolumn{3}{|c|}{ Sivas'tan tatar, sürücü ve zabtiye aracıllğıyla posta gönderilen mahaller } \\
\hline $\begin{array}{l}\text { Der-saadet ve Bağdat postaları ulaştı̆̆ında tatar ve sürücü aracılığıyla } \\
\text { posta gönderilen mahaller }\end{array}$ & Zabtiye aracıllı̆ııla ulaştırılan & Melhuzat (Bazı Açıklamalar) \\
\hline Amasya & Kangal & \multirow{4}{*}{$\begin{array}{l}\text { Aziziye ve Gürün ve Darende kazalarına gönderilecek } \\
\text { mektuplar Bağdad postasına dahil edilecek. Zabtiye ile } \\
\text { Deliktaş'a ulaştırılıp oaradan mahallerine ulaştırılır. }\end{array}$} \\
\hline Tokat & Aziziye & \\
\hline Yıldızili & Gürün & \\
\hline Divriği & Darende & \\
\hline Karayün & Zara & \multirow{3}{*}{$\begin{array}{l}\text { Her Pazarertesi günü zabtiye ile Zara'ya gönderilip oradan } \\
\text { Tozanlu ve Karahisar-1 Şarki'ye ulaştırllır. }\end{array}$} \\
\hline Kayalı & Tozanl1 & \\
\hline & Karahisar-1 Şarki & \\
\hline & Tonus merkezi Akviran & Cumaertesi günleri zabtiye-i mahsusa ile gönderilir. \\
\hline & Baharözü ile birlikte İlbeyi nahiyesi merkezi olan Söğüdcük & Pençsenbe günleri zabtiye-i mahsusa ile gönderilir. \\
\hline
\end{tabular}


Ek-6 Tokat Sancağı Telgraf Görevlileri (1870-1907)

\begin{tabular}{|c|c|c|c|c|c|}
\hline Sene & Görevli & Tokat & Erbaa & Niksar & Zile \\
\hline \multirow{2}{*}{ 1870-71 } & Telgraf Md. & Halis Efendi & 0 & 0 & 0 \\
\hline & \begin{tabular}{|l|} 
Posta Md. \\
\end{tabular} & Kamil Efendi & 0 & 0 & 0 \\
\hline \multirow{3}{*}{$1875-76$} & Telgraf ve Posta Md. & Haşim Efendi & 0 & 0 & 0 \\
\hline & \begin{tabular}{|l|} 
Telgraf Memuru \\
\end{tabular} & 0 & 0 & 0 & Agob Efendi \\
\hline & \begin{tabular}{|l|} 
Muhabere Mem. \\
\end{tabular} & Ş̈̈krü Efendi & 0 & 0 & 0 \\
\hline \multirow{7}{*}{1880} & Telgraf ve Posta Müdürü & Haşim Efendi & 0 & 0 & 0 \\
\hline & \begin{tabular}{|l|} 
Muhabere Memuru \\
\end{tabular} & Mehmed Besim Efendi & 0 & 0 & 0 \\
\hline & \begin{tabular}{|l|} 
Telgraf Memuru \\
\end{tabular} & 0 & 0 & İsmail Efendi & Haşim Efendi \\
\hline & \begin{tabular}{|l|} 
Muvassil \\
\end{tabular} & Mehmed Ağa & 0 & 0 & Yazılmamış \\
\hline & \begin{tabular}{|l|} 
Hat Çavuşu \\
\end{tabular} & Ömer Ağa & 0 & 0 & Mustafa Ağa \\
\hline & & & & & Ali Ağa \\
\hline & Şakird & İbrahim Efendi & 0 & 0 & 0 \\
\hline \multirow{8}{*}{1882} & 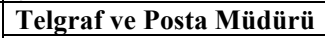 & Mehmed Tevfik Efendi & 0 & 0 & 0 \\
\hline & \begin{tabular}{|l|} 
Muhabere Memuru \\
\end{tabular} & Hüseyin Hüsnü Efendi & 0 & 0 & 0 \\
\hline & Telgraf Memuru & 0 & 0 & İsmail Efendi & Haşim Efendi \\
\hline & \multirow[t]{2}{*}{ Muvassil } & Mehmed Ağa & 0 & 0 & Yazılmamış \\
\hline & & Mustafa Ağa & 0 & 0 & 0 \\
\hline & \multirow[t]{2}{*}{ Hat Çavuşu } & Ali Ağa & 0 & 0 & Mustafa Ağa \\
\hline & & Hasan Efendi & 0 & 0 & Ali Ağa \\
\hline & \begin{tabular}{|l|} 
Şakird \\
\end{tabular} & \begin{tabular}{|l} 
İbrahim Efendi \\
\end{tabular} & 0 & 0 & 0 \\
\hline \multirow{8}{*}{1883} & \begin{tabular}{|l|l|} 
Telgraf ve Posta Müdürü \\
\end{tabular} & Hacı Halil Efendi & 0 & 0 & 0 \\
\hline & \begin{tabular}{|l|} 
Muhabere Memuru \\
\end{tabular} & Yazılmamıș & 0 & 0 & 0 \\
\hline & \begin{tabular}{|l|} 
Telgraf Memuru \\
\end{tabular} & 0 & 0 & \begin{tabular}{|l} 
İbrahim Efendi \\
\end{tabular} & Haşim Efendi \\
\hline & \multirow[t]{2}{*}{ Muvassıl } & \begin{tabular}{|l|} 
Ahmed Ağa \\
\end{tabular} & 0 & 0 & 0 \\
\hline & & Mustafa Ağa & 0 & 0 & 0 \\
\hline & \multirow[t]{2}{*}{ Hat Çavuşu } & Ali Ağa & 0 & 0 & 0 \\
\hline & & Hasan Ağa & 0 & 0 & 0 \\
\hline & \begin{tabular}{|l|} 
Şakird \\
\end{tabular} & \begin{tabular}{|l|} 
İbrahim Efendi \\
\end{tabular} & 0 & 0 & \\
\hline \multirow{8}{*}{1884} & Telgraf ve Posta Müdürü & \begin{tabular}{|l} 
Edhem Efendi \\
\end{tabular} & 0 & 0 & \\
\hline & \begin{tabular}{|l|} 
Muhabere Memuru \\
\end{tabular} & İbrahim Efendi & 0 & 0 & \\
\hline & \begin{tabular}{|l|} 
Telgraf Memuru \\
\end{tabular} & 0 & 0 & \begin{tabular}{|l} 
Edhem Efendi \\
\end{tabular} & Haşim Efendi \\
\hline & \multirow[t]{2}{*}{ Muvassil } & Ahmed Ağa & 0 & 0 & 0 \\
\hline & & Mustafa Ağa & 0 & 0 & 0 \\
\hline & \multirow[t]{2}{*}{ Hat Çavuşu } & Ali Ağa & 0 & 0 & 0 \\
\hline & & Hasan Ağa & 0 & 0 & 0 \\
\hline & \begin{tabular}{|l|} 
SSakird \\
\end{tabular} & Behçet Efendi & 0 & 0 & 0 \\
\hline \multirow{6}{*}{1886} & Telgraf ve Posta Müdürü & Edhem Efendi & 0 & 0 & 0 \\
\hline & \multirow{2}{*}{ Muhabere Memuru } & \begin{tabular}{|l} 
İbrahim Efendi \\
\end{tabular} & 0 & 0 & 0 \\
\hline & & SSevket Efendi & 0 & 0 & 0 \\
\hline & \begin{tabular}{|l|} 
Telgraf Memuru \\
\end{tabular} & 0 & 0 & Edhem Efendi & Haşim Efendi \\
\hline & \multirow[t]{2}{*}{ Muvassıl } & Ahmed Ağa & 0 & 0 & 0 \\
\hline & & Mustafa Ağa & 0 & 0 & 0 \\
\hline
\end{tabular}


Osmanlı Taşrasına Telgraf Hattı Çekilmesinde Yaşanan Zorluklar Niksar-Erbaa-Tokat Telgraf Hattı Örneği

\begin{tabular}{|c|c|c|c|c|c|c|}
\hline \multirow{8}{*}{\multicolumn{2}{|c|}{1888}} & \multirow[t]{2}{*}{ Hat Çavuşu } & Ali Ağa & 0 & $\mid 0$ & 0 \\
\hline & & & Hasan Ă̆a & 0 & 0 & 0 \\
\hline & & \begin{tabular}{|l|} 
Şakird \\
\end{tabular} & Behçet Efendi & 0 & 0 & 0 \\
\hline & & Telgraf ve Posta Müdürü & İbrahim Edhem Efendi & 0 & & \\
\hline & & \begin{tabular}{|l|} 
Baş Muhabere Memuru \\
\end{tabular} & \begin{tabular}{|l|} 
İbrahim Nadir Efendi \\
\end{tabular} & 0 & & \\
\hline & & \multirow[t]{2}{*}{ Muhabere Memuru } & Zihni Efendi & 0 & & \\
\hline & & & Ahmed Hamdi Efendi & 0 & & \\
\hline & & \begin{tabular}{|l|} 
Telgraf Memuru \\
\end{tabular} & 0 & 0 & Edhem Efendi & Haşim Efendi \\
\hline & \multirow{5}{*}{1890} & 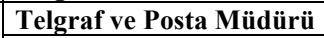 & İbrahim Edhem Efendi & 0 & & \\
\hline & & \begin{tabular}{|l|} 
Baș Muhabere Memuru \\
\end{tabular} & İbrahim Nadir Efendi & 0 & & \\
\hline & & \multirow{2}{*}{ Muhabere Memuru } & \begin{tabular}{|l|} 
İbrahim Zihni Efendi \\
\end{tabular} & 0 & & \\
\hline & & & \begin{tabular}{|l|} 
İzzet Efendi \\
\end{tabular} & 0 & 0 & 0 \\
\hline & & \begin{tabular}{|l|} 
Telgraf Memuru \\
\end{tabular} & 0 & 0 & \begin{tabular}{|l} 
Edhem Efendi \\
\end{tabular} & Haşim Efendi \\
\hline & \multirow{5}{*}{1903} & Telgraf ve Posta Müdürü & Feyzi Efendi & 0 & 0 & 0 \\
\hline & & \multirow[t]{3}{*}{\begin{tabular}{|l|} 
Muhabere Memuru \\
\end{tabular}} & Süreyye Efendi & 0 & 0 & $\begin{array}{l}\text { Haci Mehmed } \\
\text { Efendi }\end{array}$ \\
\hline 번 & & & Hamdi Efendi & 0 & 0 & 0 \\
\hline & & & \begin{tabular}{|l|} 
Faik Efendi \\
\end{tabular} & 0 & 0 & 0 \\
\hline HISTORY & & \begin{tabular}{|l|} 
Telgraf ve Posta Memuru \\
\end{tabular} & 0 & Kamil Efendi & \begin{tabular}{|l} 
İbrahim Edhem Efendi \\
\end{tabular} & \begin{tabular}{|l|} 
Sükrü Efendi \\
\end{tabular} \\
\hline STUDIES & \multirow{8}{*}{1907} & Telgraf ve Posta Müdürü & Edhem Efendi & 0 & Edhem Efendi & Haşim Efendi \\
\hline \multirow{4}{*}{99} & & \multirow[t]{3}{*}{ Muhabere Memuru } & Halim Efendi & & & İbrahim Efend \\
\hline & & & \begin{tabular}{|l|} 
Adil Efendi \\
\end{tabular} & & & \\
\hline & & & Osman Efendi & & & \\
\hline & & \begin{tabular}{|l|} 
Muvassil-1 Muharrerat \\
\end{tabular} & 0 & 0 & 0 & Șerif Efendi \\
\hline \multirow{3}{*}{$\begin{array}{l}\text { Volume } 9 \\
\text { Issue } 4\end{array}$} & & \multirow[t]{2}{*}{ Hat Çavuşu } & 0 & 0 & 0 & Mustafa Ağa \\
\hline & & & 0 & 0 & 0 & Mehmed Ağa \\
\hline & & \begin{tabular}{|l} 
Telgraf ve Posta Memuru \\
\end{tabular} & 0 & Mehmed Kamil Efendi & 0 & 0 \\
\hline
\end{tabular}

